\title{
Holocene environments and climate in the Mongolian Altai reconstructed from the Hoton-Nur pollen and diatom records: a step towards better understanding climate dynamics in Central Asia
}

\author{
Natalia Rudaya ${ }^{\mathrm{a}, 1}$, Pavel Tarasov ${ }^{\mathrm{b}, *, 1}$, Nadezhda Dorofeyuk ${ }^{\mathrm{c}}$, Nadia Solovieva ${ }^{\mathrm{d}}$, Ivan Kalugin ${ }^{\mathrm{e}}$, \\ Andrei Andreev ${ }^{\mathrm{f}}$, Andrei Daryin ${ }^{\mathrm{e}}$, Bernhard Diekmann ${ }^{\mathrm{f}}$, Frank Riedel ${ }^{\mathrm{b}}$, \\ Narantsetseg Tserendash ${ }^{\mathrm{g}}$, Mayke Wagner ${ }^{\mathrm{h}}$ \\ a Institute of Archaeology and Ethnography SB RAS, Ak. Lavrentieva 17, Novosibirsk 630090, Russia \\ ${ }^{\mathrm{b}}$ Palaeontology Department, Institute of Geological Sciences, Free University of Berlin, Malteserstrasse 74-100, Building D, Berlin 12249, Germany \\ ${ }^{\mathrm{c}}$ Severtsov Institute of Ecology and Evolution RAS, Leninsky Prospect 33, Moscow 119071, Russia \\ ${ }^{\mathrm{d}}$ Department of Geography, University College London, Gower Street, London WC1E 6BT, UK \\ ${ }^{\mathrm{e}}$ Trofimuk United Institute of Geology, Geophysics and Mineralogy SB RAS, Ak. Koptyuga 3, Novosibirsk 630090, Russia \\ ${ }^{\mathrm{f}}$ Alfred Wegener Institute for Polar and Marine Research, Research Unit Potsdam, Telegrafenberg A43, 14473 Potsdam, Germany \\ ${ }^{\mathrm{g}}$ Institute of Geology and Mineral Resources of MAS, Enkhtaivnii orgon choloo, 63 Bayanzurkh duureg, Ulaanbaatar 210351, Mongolia \\ ${ }^{\mathrm{h}}$ Department of Eurasian Archaeology, German Archaeological Institute, Im Dol 2-6 House 2, Berlin 14195, Germany
}

\section{A R T I C L E I N F O}

\section{Article history:}

Received 15 July 2008

Received in revised form

7 October 2008

Accepted 13 October 2008

Available online $\mathrm{xxx}$

\begin{abstract}
A B S T R A C T
This study presents the results of the palynological and diatom analyses of the sediment core recovered in Hoton-Nur Lake $\left(48^{\circ} 37^{\prime} 18^{\prime \prime} \mathrm{N}, 88^{\circ} 20^{\prime} 45^{\prime \prime} \mathrm{E}, 2083 \mathrm{~m}\right)$ in 2004 . Quantitative reconstruction of the Holocene vegetation and climate dynamics in the semiarid Mongolian Altai suggests that boreal woodland replaced the primarily open landscape of northwestern Mongolia at about $10 \mathrm{kyr} \mathrm{BP}(1 \mathrm{kyr}=1000 \mathrm{cal} \mathrm{yr})$ in response to a noticeable increase in precipitation from $200-250 \mathrm{~mm} / \mathrm{yr}$ to $450-550 \mathrm{~mm} / \mathrm{yr}$. A decline of the forest vegetation and a return to a predominance of open vegetation types occurred after $5 \mathrm{kyr}$ BP when precipitation sums decreased to $250-300 \mathrm{~mm} / \mathrm{yr}$. Prior to $11.5 \mathrm{kyr}$ PB diatom concentrations are relatively low and the lake is dominated by planktonic Cyclotella and small Fragilariaceae, suggesting the existence of a relatively deep and oligotrophic/mesotrophic lake. The great abundance of Staurosirella pinnata from the beginning of the record until $10.7 \mathrm{kyr}$ BP might imply intensified erosion processes in the catchment and this is fully consistent with the presence of scarce and dry vegetation and the generally arid climate during this period. From about $10.7 \mathrm{kyr}$ BP, more planktonic diatom taxa appeared and increased in abundance, indicating that the lake became more productive as diatom concentration increased. This change correlates well with the development of boreal woodland in the catchment. Decrease in precipitation and changes in the vegetation towards steppe are reflected by the rapid increase in Aulacoseira distans from about $5 \mathrm{kyr}$ BP. The Holocene pollen and diatom records do not indicate soil and vegetation cover disturbances by the anthropogenic activities, implying that the main transformations of the regional vegetation occurred as a result of the natural climate change. Our reconstruction is in agreement with the paleomonsoon records from China, demonstrating an abrupt strengthening of the summer monsoon at $12 \mathrm{kyr} \mathrm{BP}$ and an associated increase in precipitation and in lake levels between 11 and $8 \mathrm{kyr}$ BP, followed by the stepwise attenuation of the monsoon circulation and climate aridization towards the modern level. The records from the neighboring areas of Kazakhstan and Russia, situated west and north of Hoton-Nur, demonstrate spatially and temporally different Holocene vegetation and climate histories, indicating that the Altai Mountains as a climate boundary are of pivotal importance for the Holocene environmental and, possibly, habitation history of Central Asia.
\end{abstract} (c) 2008 Published by Elsevier Ltd.

\section{Introduction}

* Corresponding author. Tel.: +49308387 0280; fax: +493083870745.
E-mail address: paveltarasov@mail.ru (P. Tarasov).
1 These authors contributed equally to this paper.

Mongolia lies in the centre of Asia. It comprises an area of $1.566 \times 10^{6} \mathrm{~km}^{2}$ and has an average population density of less than two people per square kilometer. Mongolia experienced a peak in 
the paleoenvironmental studies during the 1970s-80s when radiocarbon-dated sedimentary records from over twenty lakes and key sequences were published in Russian (see Gunin et al., 1999 for detailed summary). During the past ten years a few publications reporting new results of paleoenvironmental studies have appeared in English (Grunert et al., 2000; Peck et al., 2002; Fowell et al., 2003; Miehe et al., 2007; Prokopenko et al., 2007; Schlütz et al., 2008).

The current study is primarily focused on Hoton-Nur (also known as Khoton Nuur), a large fresh-water lake in the Mongolian Altai (Fig. 1). The lake was first cored in 1980 and the core sediments were radiocarbon dated and coarsely analyzed for pollen and diatoms (Tarasov et al., 1994). These records indicate an amelioration of the regional climate in the early-mid-Holocene and a shift towards drier environments during the late Holocene (Gunin et al., 1999; Tarasov et al., 2000). Such pattern resembles climatic change reconstructed in monsoonal China, but is notably different from that recorded in the regions controlled by the Atlantic air masses (Tarasov et al., 2007b).

The Altai Mountains with elevations above $4500 \mathrm{~m}$ and an extension of more than $1200 \mathrm{~km}$ is the most prominent sublongitudinal mountain range in Central Asia. The northwest part of the range (also known as the Russian Altai or simply the Altai) merges with the Sayan Mountains in the east and with the Mongolian Altai in the south. From the northwestern corner of Mongolia the range extends southeast, where it gradually becomes lower and finally merges into the high plateau of the Gobi Desert. The location of the Altai Mountains in the centre of Asia at the

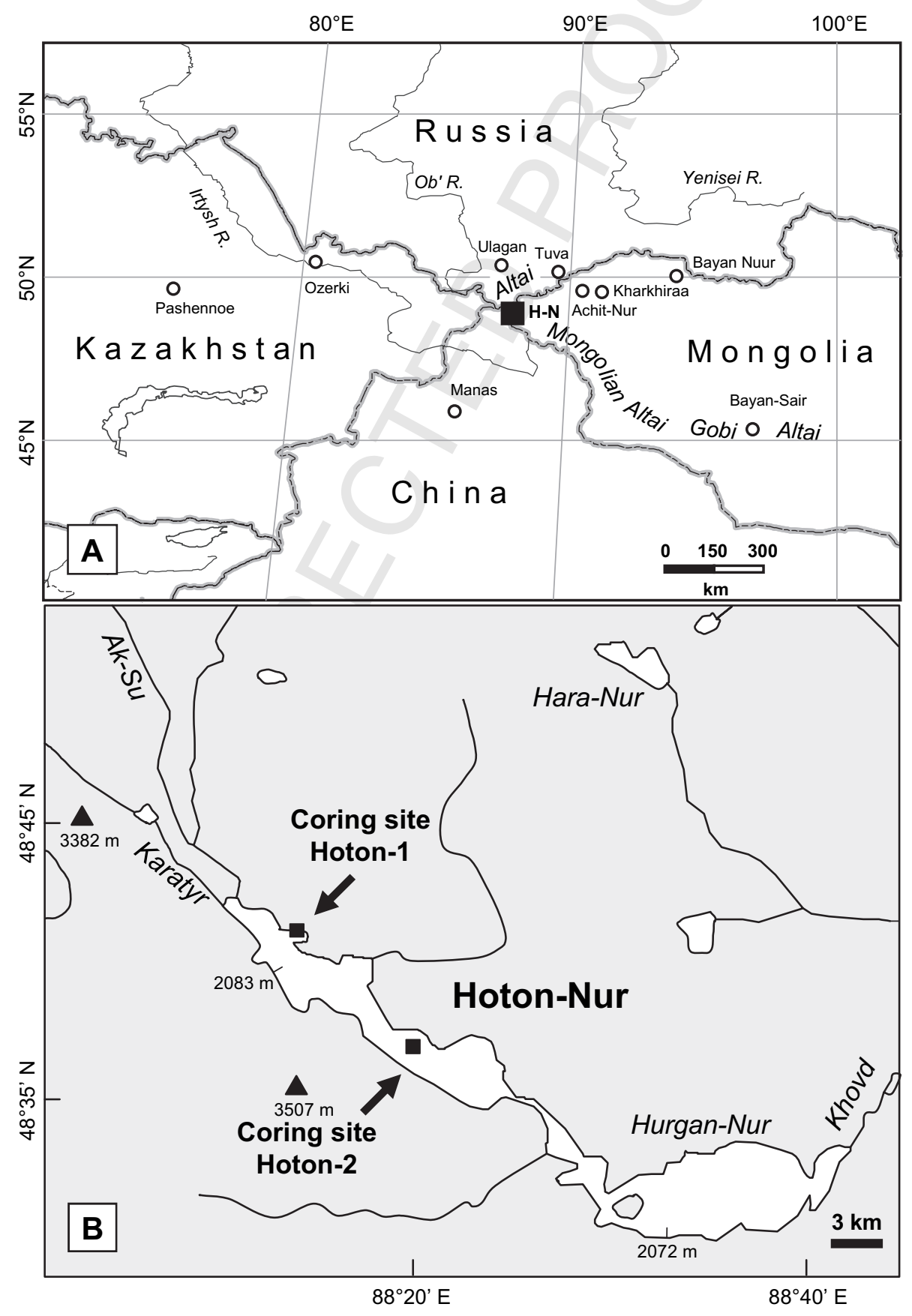

Fig. 1. Map of Central Asia (A) and the region around Hoton-Nur with locations of the analyzed pollen and diatom records (B). 
limits of both Pacific and Atlantic influences implies that this mountain system is an important climatic boundary in Central Asia, and thus requires careful investigation.

In this paper we present (i) the results of the fine-resolution palynological and diatom analyses of the sediment core recovered from Hoton-Nur in 2004; (ii) quantitative reconstructions of the Holocene lacustrine environments, vegetation and climate; further, (iii) we interpret these new results in terms of the regional environmental dynamics in the Mongolian Altai, and (iv) discuss them together with the environmental records from the neighboring regions of Kazakhstan, Russia and China.

\section{Regional setting}

Hoton-Nur $\left(48^{\circ} 40^{\prime} \mathrm{N}, 88^{\circ} 18^{\prime} \mathrm{E}, 2083 \mathrm{~m}\right)$ is situated in the intermountain depression in the sparsely populated northern part of the Mongolian Altai (Fig. 1). The lake has an area of $50 \mathrm{~km}^{2}$ with a maximum water depth of $58 \mathrm{~m}$ (see Tarasov et al., 1994 for details and references). It has inflow from the rivers Karatyr, Ak-Su and several small streams and outflow southward to Hurgan-Nur and further to the Khovd River. Geomorphological and geological investigations suggest that the formation of the Hoton-Nur basin occurred during the late Pleistocene, when the valley was dammed by the end moraine deposits of the mountain glaciers. Earlier studies suggest that during the late Pleistocene mountain glaciers extended to lower elevations than they do at present, but, because of the dry climate, did not occupy large areas in the region. However, the history of the Pleistocene glaciation in the Mongolian Altai is still not satisfactorily understood (Gunin et al., 1999).

The climate around Hoton-Nur is characterized by long, cold, dry winters and short, cool, relatively wet summers (National Atlas, 1990). Mean temperatures vary between -20 and $-25^{\circ} \mathrm{C}$ in January and are about $12-15^{\circ} \mathrm{C}$ in July. Mean annual precipitation $\left(P_{\mathrm{ann}}\right)$ is around $250 \mathrm{~mm}$ at the lake level, reaching $300 \mathrm{~mm}$ at elevations above $3000 \mathrm{~m}$. The bioclimatic variables calculated by a weighted distance interpolation method applied to the global meteorological dataset representing the 1961-1990 observation interval (Leemans and Cramer, 1991) are $-20^{\circ} \mathrm{C}$ for mean January (coldest month) temperature $\left(T_{\mathrm{C}}\right), 14^{\circ} \mathrm{C}$ for mean July (warmest month) temperature $\left(T_{\mathrm{j}}\right)$ and 0.45 for moisture index ( $\alpha$-ratio of actual over potential evapotranspiration sensu Prentice et al., 1992), corresponding to the present-day cool steppe biome (Tarasov et al., 2000).

Modern vegetation distribution in the Mongolian Altai reflects its cold and semi-arid climate modified by the altitude and slope orientation (Volkova, 1994). In the lower alpine belt ( $3000 \mathrm{~m})$ vegetation is dominated by shrubby birch (Betula rotundifolia) and northern willow (Salix glauca), grasses and sedges. Steppe communities generally occur in the elevation belt between 1800 and $2400 \mathrm{~m}$, but may penetrate up to $3200 \mathrm{~m}$ a.s.l. In the eastern and northern parts of the Hoton-Nur basin cold-tolerant steppe vegetation is widespread and often intercalated with kobresian and sedge communities. Semi-desert vegetation grows in the dry isolated intermountain basins. A narrow and discontinuous forest belt dominated by larch (Larix sibirica) and spruce (Picea obovata) occurs in the western and north-western part of the Mongolian Altai at the altitudes of $1900-2000 \mathrm{~m}$ a.s.l. L. sibirica open stands were described north of Hoton-Nur and in the upper part of the Ak-Su River valley (National Atlas, 1990; Volkova, 1994) and closest P. obovata stand is located $50 \mathrm{~km}$ north of the lake. Pollen of a few other tree taxa was identified in the Hoton-Nur record, including Siberian pine (Pinus sibirica), Scots pine (P. sylvestris) and fir (Abies sibirica). The nearest to Hoton-Nur $P$. sibirica woods grow about $50 \mathrm{~km}$ north of the lake in the Tsagan-Gol and Ak-Su River valleys. $P$. sylvestris and $A$. sibirica distribution areas do not reach the Mongolian Altai (National Atlas, 1990; Gunin et al., 1999) and are restricted to the Russian and Kazakh parts of the Altai Mountains (Alpat'ev et al., 1976; Ogureeva, 1980).

The area of the Olgiy Aymag, where Hoton-Nur is located, is home to about eighty thousand people (National Atlas, 1990). The traditional life style of the local population is nomadic and animal breeding is the main occupation. Present-day anthropogenic pressure on the ecosystems may reach the moderate to high level in the river valleys and in the coastal area around Hoton-Nur mainly due to overgrazing (Ecosystems of Mongolia. Atlas, 2005).

\section{Data and methods}

\subsection{Coring and lithology}

In August 2004, the $257 \mathrm{~cm}$ long sediment core (Hoton-2) was recovered from $32 \mathrm{~m}$ depth in the southeastern part of Hoton-Nur $\left(48^{\circ} 37^{\prime} 18^{\prime \prime} \mathrm{N}, 88^{\circ} 20^{\prime} 45^{\prime \prime} \mathrm{E}\right.$, Fig. 1b). Coring was carried out by a gravity corer of $100 \mathrm{~mm}$ diameter with a blade catcher. The recovered core consists of compact inorganic gray-blue clay (below $205 \mathrm{~cm}$ ) and striate gray clay and silt (above $205 \mathrm{~cm}$ ) with a touch of organic matter (Fig. 3). A sharp boundary between the two units may point to a sedimentary hiatus. However, such suggestion requires further proof. The grain-size analysis of the core material performed with a $0.5 \mathrm{~cm}$ step shows very little variations in the median diameter of the sedimentary particles (Fig. 3). Quartz, feldspar, light and brownish mica are identified in the mineral composition of the core. The sediment composition shows a slight change towards an increase in the contents of $\mathrm{Fe}_{2} \mathrm{O}_{3}, \mathrm{TiO}_{2}$ and $\mathrm{MgO}$ and a slight decrease in $\mathrm{SiO}_{2}$ and magnetization between 185 and $150 \mathrm{~cm}$. Gradual changes in the vegetation cover and/or in availability of the eroded moraine sediments in the lake catchment area can both be invoked to explain these minor lithological changes.

\subsection{Radiocarbon dating and age-depth model}

Small organic remains from the Hoton-2 core were hand-picked and for accelerator-mass spectrometer (AMS) dating. The analysis of six samples among them showed not enough material for the dating. Among the remaining four samples (Table 1), two demonstrated ages exceeding the limit of the ${ }^{14} \mathrm{C}$ method. The older ages are related to the scarcity of the organic material and reworked character of the found non-identifiable particles. The sample from $236.5-237 \mathrm{~cm}$ depth was dated to $32,450 \pm 380{ }^{14} \mathrm{C}$ yr BP, suggesting that the lower clay unit accumulated during the late Pleistocene. Alternatively, this date could be also interpreted as being too old. The date $9130 \pm 40{ }^{14} \mathrm{C}$ yr BP obtained for the

Table 1

AMS and conventional ${ }^{14} \mathrm{C}$ dates from the Hoton-2 (this study) and Hoton-1 (Tarasov et al., 2000) core sediments.

\begin{tabular}{|c|c|c|c|}
\hline $\begin{array}{l}\text { Core depth, } \\
\mathrm{cm}\end{array}$ & $\begin{array}{l}{ }^{14} \mathrm{C} \text { ages } \\
\left({ }^{14} \mathrm{C} \text { yr BP }\right)\end{array}$ & $\begin{array}{l}\text { Calibrated }{ }^{14} \mathrm{C} \text { ages } \\
\text { (cal yr BP) }\end{array}$ & $\begin{array}{l}\text { Laboratory } \\
\text { no. }\end{array}$ \\
\hline \multicolumn{4}{|l|}{ Hoton-2 core } \\
\hline $49.5-50$ & $55000+5220 /-3140$ & Age is too old & KIA32074 \\
\hline $144.5-145$ & $53580+2870 /-2110$ & Age is too old & KIA32075 \\
\hline $174.5-175$ & $9130 \pm 40$ & $10304 \pm 56$ & KIA32076 \\
\hline $236.5-237$ & $32450 \pm 380$ & Age is possibly too old & KIA29869 \\
\hline \multicolumn{4}{|l|}{ Hoton-1 core } \\
\hline 70-95 & $2950 \pm 80$ & $3122 \pm 119$ & TA-1471 \\
\hline $147-170$ & $3900 \pm 140$ & $4331 \pm 199$ & TA-1440 \\
\hline $195-220$ & $5360 \pm 80$ & $6141 \pm 106$ & TA-1472 \\
\hline $245-270$ & $5975 \pm 150$ & $6841 \pm 188$ & TA-1439 \\
\hline $295-320$ & $7910 \pm 120$ & $8780 \pm 166$ & TA-1473 \\
\hline $350-375$ & $9070 \pm 150$ & $10195 \pm 229$ & TA-1419 \\
\hline
\end{tabular}

Calibration was performed using the latest version of the CalPal University of Cologne Radiocarbon Calibration Program Package (http://www.calpal.de). 
$174.5-175 \mathrm{~cm}$ level seemed to be the only reliable one. However, it was held to be insufficient for reliable age control given the poor quality of the other dates.

In order to construct an adequate age-depth model for the Hoton-2 core and to verify the reliability of its single date we decided to include in the analysis ${ }^{14} \mathrm{C}$ dates obtained for the Hoton1 core recovered in 1980 (Tarasov et al., 1994). The earlier core was taken from the central part of a relatively small bay located in the northeastern part of Hoton-Nur at a water depth of $4.8 \mathrm{~m}$ (Fig. 1b). The distance between the Hoton- 1 and Hoton- 2 coring sites is $\sim 11 \mathrm{~km}$. The near-shore location of the Hoton- 1 site in the semiclosed bay, stable sedimentation environments without river inflows and high organic content of the Hoton- 1 core sediment allowed to obtain a sequence of $\operatorname{six}{ }^{14} \mathrm{C}$ dates (Table 1 ).

For the purpose of this study we performed the following steps: (i) calibrated radiocarbon dates from Hoton-1 core (Table 1); (ii) applied the established age-depth model to the Hoton-1 pollen record; (iii) compared Hoton- 1 and Hoton-2 pollen records and transferred ages of all coinciding changes in the relative abundance of the 21 terrestrial pollen taxa commonly identified in both records from the Hoton-1 age model to the Hoton- 2 record; and (iv) used the resulting set of calibrated ages inferred via pollen-based correlation of two records to construct the age-depth model for the Hoton-2 records presented in this study (Fig. 2). The age-depth model represents a regression line with the second-degree polynomial fit. To our satisfaction the earlyHolocene date from the Hoton- 2 core (Table 1) fitted well into the newly constructed age-depth model, thus strengthening the Hoton-2 chronology. However, we left unresolved the age determination for the lower part of the Hoton-2 core $(205-257 \mathrm{~cm})$. In this paper, calibrated ages before present (expressed as kyr BP, where $1 \mathrm{kyr}=1000 \mathrm{cal} \mathrm{yr}$ ) are used throughout the text.

\subsection{Pollen analysis}

A total of 100 samples, each consisting of one or two grams of the dry sediment taken with an average interval of $2.5 \mathrm{~cm}$ from the Hoton-2 core, were treated for pollen analysis using standard procedure (Faegri and Iversen, 1989). Lycopodium spore tablets were added to each sample in order to calculate total pollen and spore concentration. Pollen residues mounted in glycerin were analyzed under the light microscope with $\frown \mathrm{a} \times 400-1000$ magnification. The identification of the pollen and spores was performed using reference pollen collection and regional pollen atlases (Kuprianova and Alyoshina, 1972; Reille, 1992, 1998).

In total, 51 pollen and spore taxa representing vascular plants were identified in the Hoton-2 core (Appendix A), e.g. 2.5 times more than in the low-resolution Hoton-1 record. In this study pollen of Pinus was separated into two morphological types. In the study area and surrounding regions these two pollen types are produced by $P$. sylvestris and $P$. sibirica trees, respectively. Betula pollen was also divided into two morphological types- $B$. sect. Nanae (shrub birch) and $B$. sect. Albae (tree birch).

The microscopic analysis revealed moderately high pollen concentration and generally good preservation of pollen grains in the upper sedimentary unit $(0-205 \mathrm{~cm})$, allowing an easy counting of up to 500 terrestrial pollen grains per sample. However, pollen spectra from the lower unit demonstrated extremely low pollen concentration, which resulted in counting of less than 100 terrestrial pollen grains per sample. Such low pollen sums are not recommended for further statistical analysis (Faegri and Iversen, 1989). Conventionally, we showed only a presence or absence of a certain pollen taxon in the pollen diagram below $205 \mathrm{~cm}$ depth (Fig. 3). For the remaining spectra, percentages were calculated based on a total sum of all pollen taxa taken as $100 \%$.

\subsection{Non-pollen palynomorphs}

Samples prepared for the pollen analysis were also used to count coniferous stomata and other recognizable non-pollen palynomorphs (NPP). Identification of stomata was carried out using published reference keys (Trautmann, 1953; Sweeney, 2004); fungi spores, remains of green algae colonies, eggs of Tardigrada and chironomid remains were identified using descriptions, pictures and photographs published by Jankovska (1991), van Geel, 2001, and Komarek and Jankovska (2001). The NPP counts are Q4 provided in Appendix $A$ and the simplified results are plotted together with the results of pollen analysis (Fig. 3).

\subsection{Diatom analysis}

A total of 58 samples, picked up with the 5-cm step, were prepared for diatom analysis using the standard technique and

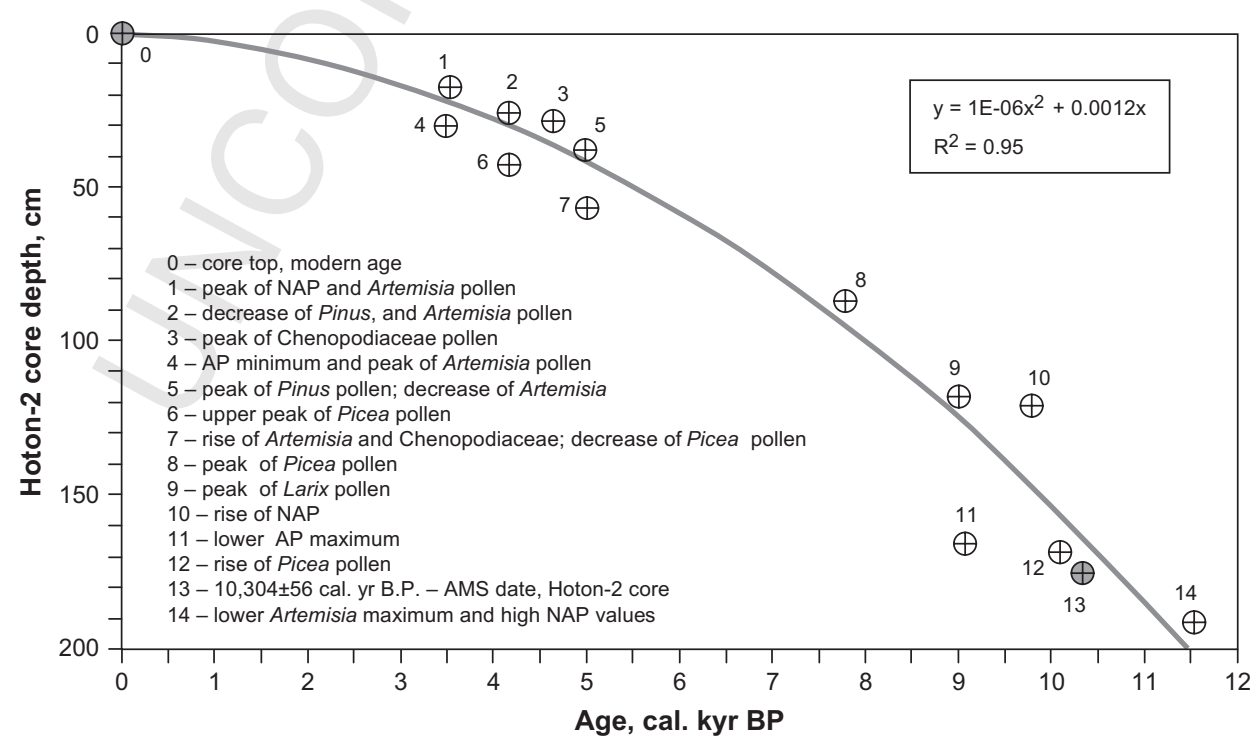

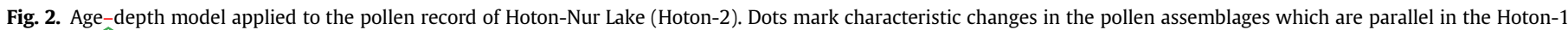
(Tarasov et al., 2000) and Hoton-2 (this study) pollen records. 


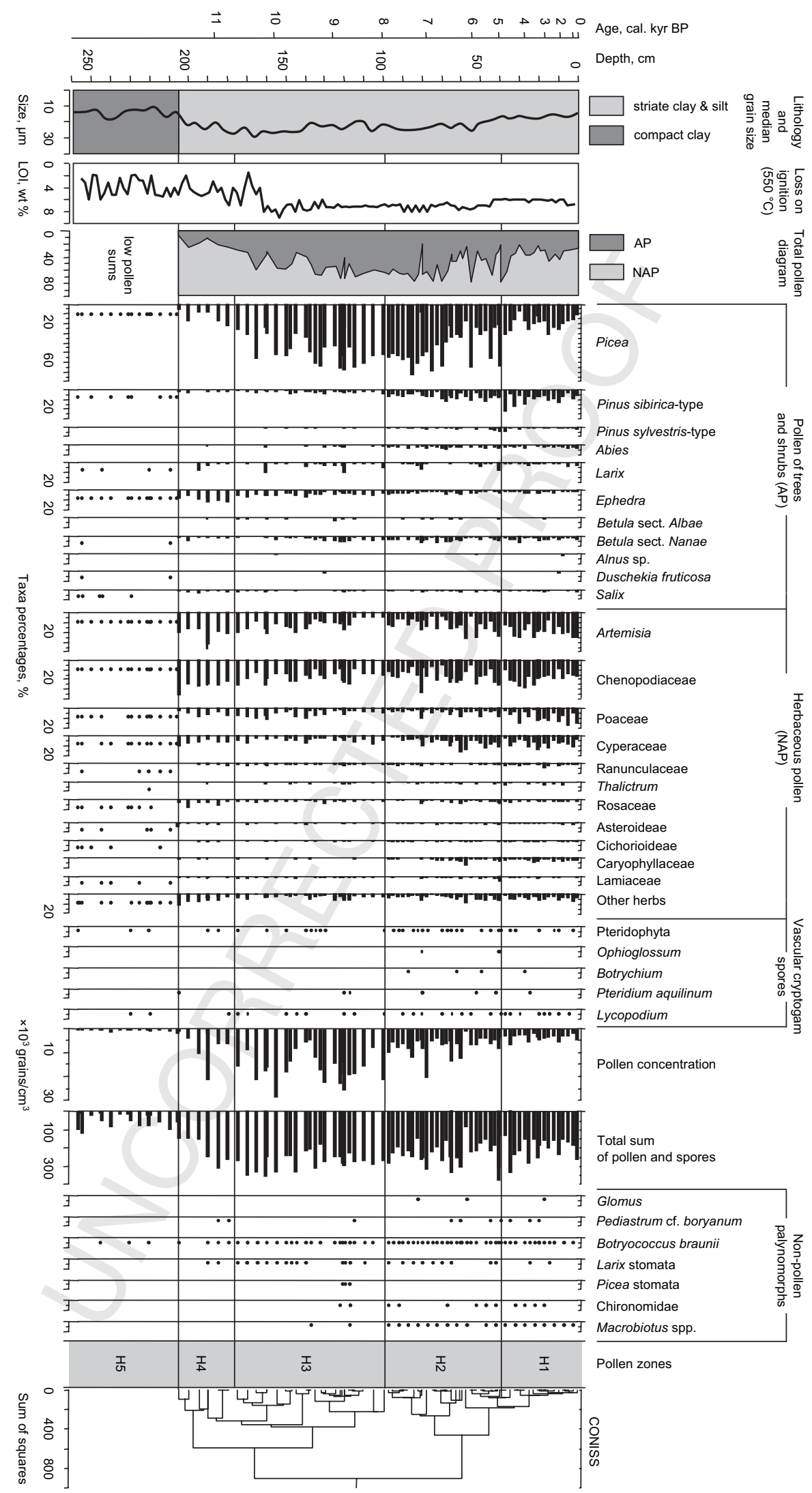

Fig. 3. Diagram presenting lithological characteristics and results of palynological analysis of the Hoton-2 core produced with the Tilia/TiliaGraph software (Grimm, 1991). The visual definition of the pollen zones is supported by CONISS (Grimm, 1987). Black dots indicate presence of a certain taxon in the given spectrum (see Appendix A for further details).

Please cite this article in press as: Rudaya, N., et al., Holocene environments and climate in the Mongolian Altai reconstructed from the HotonNur..., Quaternary Science Reviews (2008), doi:10.1016/j.quascirev.2008.10.013 
disintegration method in hydrogen peroxide (Battarbee, 1986). Aliquots of evaporated suspensions were embedded in Naphrax. At least 500-600 diatom valves per sample were counted on horizontal transects in the light microscope with phase-contrast oil immersion objectives at $\times 750$ magnification. Diatom concentrations were calculated using an equation (Schrader, 1974) adapted for the continental diatoms (Davydova, 1985). Diatom nomenclature followed Krammer and Lange-Bertalot (1986-1991). The total sum of all diatoms counted in each sample (Appendix B) was taken as $100 \%$, based upon which the relative abundances of individual taxa were calculated in order to construct the diatom diagram (Fig. 4).

To facilitate discussion of the diatom record, we accepted the following abundance classes for the individual taxa (Dorofeyuk and Tsetsegmaa, 2002): $<1 \%=$ rare; $1-5 \%=$ common; $5-10 \%=$ subdominant; and $>10 \%=$ dominant. The AL:PE diatom-pH model was used for $\mathrm{pH}$ inference (Cameron et al., 1999). The $\mathrm{pH}$ reconstruction (Fig. 4) was performed with the aid of the internet-based European Diatom Database (http://craticula.ncl.ac.uk/Eddi/jsp/index. jsp) facility. Summary prediction statistics are given in Table 2. Inverse regression was chosen for the presentation of the final results as it generated a slightly lower root mean square error of prediction (RMSEP).

\subsection{Quantitative methods of vegetation and climate reconstruction}

The method applied in the biome reconstruction is a quantitative approach introduced by Prentice et al. (1996) which has proved to be a powerful tool for the objective vegetation reconstruction from the late Quaternary pollen data and for data-model comparison (Texier et al., 1997; Prentice et al., 2000). The method has been adapted for the reconstruction of the northern Eurasian, particularly Mongolian biomes (Tarasov et al., 1998, 2000; Gunin et al., 1999). In this paper we use the biome-taxon matrix and calculation equation proposed in the latter studies, in which all commonly identified pollen taxa are attributed to ten biomes growing in Mongolia and in northern Eurasia. When applied to 102 surface pollen spectra from Mongolia, this method assigns 83\% of the samples to the correct biome (Gunin et al., 1999).

The pollen records from Mongolia have been frequently used for qualitative interpretation of the Holocene climate (Gunin et al., 1999; Grunert et al., 2000; Tarasov et al., 2000; Fowell et al., 2003; Prokopenko et al., 2007). In this study we applied the quantitative technique known as the "best modern analogue (BMA) method" (Overpeck et al., 1985; Guiot, 1990) to the Hoton-Nur pollen records in order to reconstruct atmospheric precipitation-a climatic variable, which controls regional vegetation distribution (Alpat'ev et al., 1976; Gunin et al., 1999). The BMA method was tested using an extensive surface pollen and meteorological datasets from northern Eurasia and Mongolia, and performance statistics demonstrated a capability to reproduce modern bioclimatic variables with a high degree of confidence (e.g. Solovieva et al., 2005). In the present study we used the BMA design and reference modern pollen/climate datasets from Tarasov et al. (2007a), who applied the method to the Eemian and Holocene pollen records from Lake Baikal. In the reference data set, the sum of 81 terrestrial pollen taxa from northern Eurasia, including all taxa identified in the Hoton-1 and Hoton-2 records, is taken as $100 \%$. All calculations were performed with Polygon 1.5 software (Nakagawa et al., 2002; http://dendro.naruto-u.ac.jp/ nakagawa/).

\section{Analytical results}

\subsection{Pollen}

The Hoton-2 pollen diagram (Fig. 3) is subdivided into five pollen zones (PZ) on the basis of changing pollen taxa composition and abundance. Below we provide a brief characteristic of the Hoton-2 pollen zones from the bottom to the top of the core.

PZ H5 (257-205 cm, >11.5 kyr BP). The pollen concentrations (up to $1.8 \times 10^{3}$ grains $/ \mathrm{cm}^{3}$ ) and abundances are extremely low preventing from the pollen percentage calculation. Pollen of non-arboreal (NAP) taxa, including Chenopodiaceae, Artemisia, Cyperaceae and Ephedra are relatively abundant (Appendix A). Only single grains of Picea, $P$. sibirica-type and Larix representing arboreal pollen (AP) taxa are found.

PZ H4 (205-175 cm, 11.5-10.7 kyr BP) is characterized by the high pollen concentrations (up to $21 \times 10^{3}$ grains $/ \mathrm{cm}^{3}$ ) and the predominance of herbaceous taxa (up to $85 \%$ ) including Chenopodiaceae (up to 35\%) and Artemisia (up to 35\%). The content of both Cyperaceae and Poaceae pollen may reach $10 \%$ and the relative abundance of Ephedra pollen may reach up to 15\%. Among the AP taxa Picea predominates over P. sibirica-type and Larix.

PZ H3 (175-97.5 cm, 10.7-7.9 kyr BP). This zone reveals the highest pollen concentrations (up to $25 \times 10^{3}$ grains $/ \mathrm{cm}^{3}$ ) and a sharp increase in AP percentages (up to $75 \%$ ). The Picea pollen content may reach $70 \%$ and percentages of $P$. sibirica-type, Larix and $B$. sect. Nanae pollen also become higher in this zone. Among the NAP taxa a relative increase in Poaceae percentages is noticeable.

PZ H2 (97.5-40 cm, 7.9-4.9 kyr BP). This zone is notable for the decrease in pollen concentrations (up to $20 \times 10^{3}$ grains $/ \mathrm{cm}^{3}$ ) accompanied by abrupt variations in the AP and NAP taxa percentages, e.g. the content of Picea varies between $10 \%$ and $75 \%$. Abies reaches its maximum (4\%) and P. sibirica-type amounts to $15 \%$. Among herbaceous pollen taxa Artemisia, Chenopodiaceae, Poaceae, and Cyperaceae are most abundant.

PZ H1 (40-0 cm, 4.9-0 kyr BP) shows a general decrease in pollen concentrations (up to $6.3 \times 10^{3}$ grains $/ \mathrm{cm}^{3}$ ) and in $\mathrm{AP}$ percentages. Picea pollen abundance varies between $10 \%$ and $40 \%$. However, $P$. sibirica-type percentages reach a maximum in this zone. The share of NAP increases to $60-70 \%$, and Artemisia, Chenopodiaceae, Poaceae and Cyperaceae remain among the dominant taxa.

\subsection{Non-pollen palynomorphs}

Coniferous stomata are found in a total of 27 samples, representing all pollen zones, except for the lowermost PZ H5 (Fig. 3). Their abundance is generally low and does not exceed 5 stomata per sample (Appendix A). The Larix stomata are found in 27 samples, more frequently in PZ H3 and PZ H2 and only occasionally in PZ H4 and PZ H1, while stomata of Picea are found only in 3 samples from PZ H3.

Other NPP are also found in relatively low numbers (Appendix A). Remains of colonial green alga Botryococcus braunii show the highest frequencies and appear already in PZ H5 (Fig. 3), where no other NPP are found. $B$. braunii is a widely distributed alga inhabiting lakes and rivers from the arctic to tropical latitudes. It is mainly observed in the upper photic zone and is most characteristic of the oligotrophic lakes, although occurrence in the mesotrophic waters is possible (Tyson, 1995; Smittenberg et al., 2005). In PZ H4, except B. braunii few remains of colonial alga Pediastrum cf. boryanum are found in 2 samples. In PZ $\mathrm{H} 3$, except permanently present $B$. braunii, $P$. cf. boryanum is found in one sample and eggs of Macrobiotus hibernicus and M. hufelandi representing Tardigrada appear in the sediments younger than $9.5 \mathrm{kyr}$ BP. Between $8 \mathrm{kyr}$ BP and the core top their content is fairly stable, e.g. 2-7 eggs per sample. Jaws of chironomids (Cladotanytarsus and Mesocricotopus) are also found (1-7 per sample) in the PZ H3 in the sediment younger than $9 \mathrm{kyr}$ BP. Single Glomus spores are found in two samples from PZ H2 and in one sample from PZ H1.

\subsection{Diatoms and reconstructed $p H$}

Dorofeyuk and Tsetsegmaa (2002) reported that the modern diatom flora of Hoton-Nur consists 57 taxa. The fossil diatom flora 


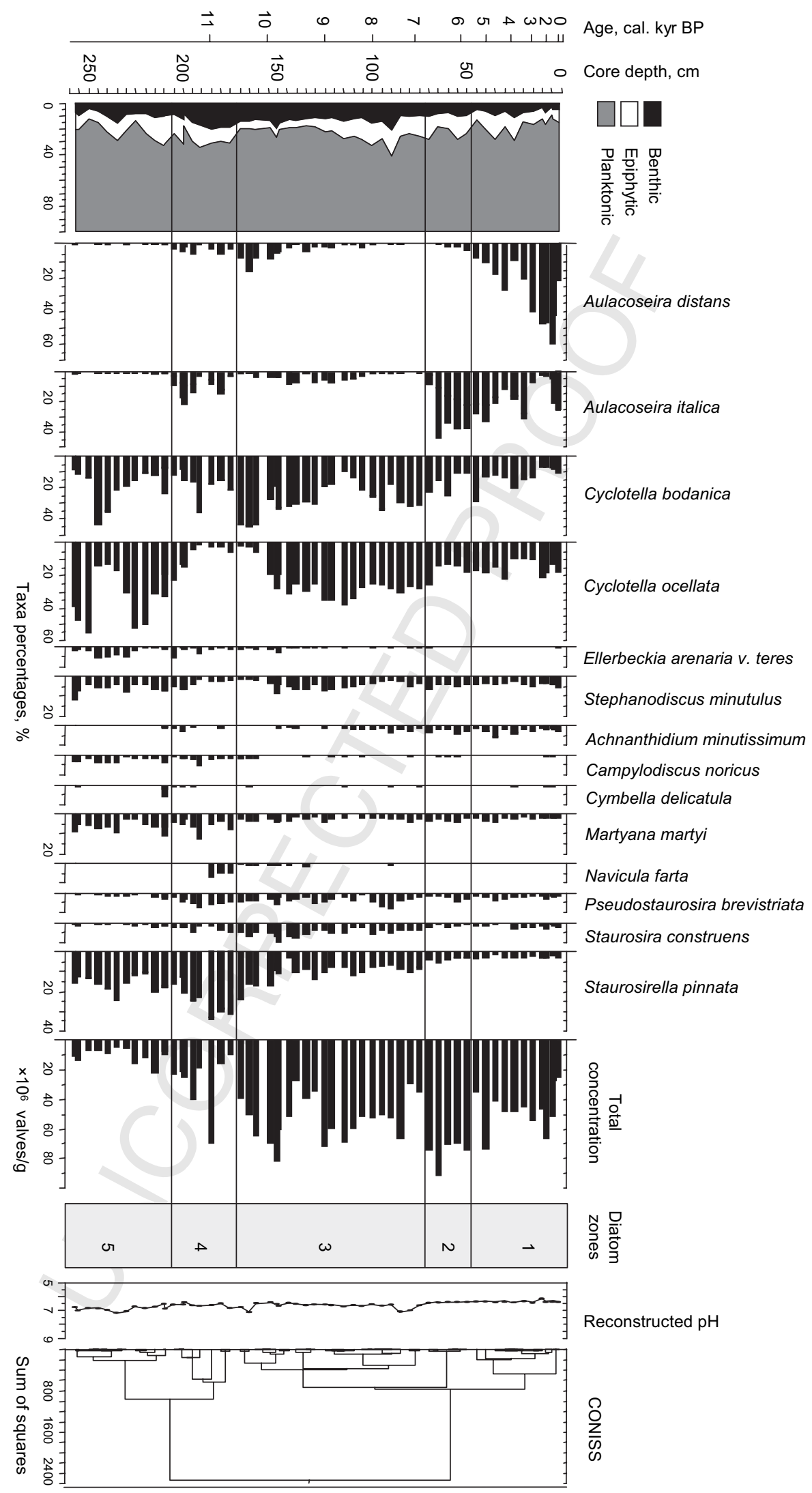

Fig. 4. Diatom stratigraphy and AL:PE-reconstructed pH from the Hoton-2 core. Construction of the diatom diagram was performed with Tilia/TiliaGraph software (Grimm, 1991), and local diatom zone boundaries were drawn on the basis of the visual inspection supported by CONISS (Grimm, 1987).

Please cite this article in press as: Rudaya, N., et al., Holocene environments and climate in the Mongolian Altai reconstructed from the HotonNur..., Quaternary Science Reviews (2008), doi:10.1016/j.quascirev.2008.10.013 
Table 2

Apparent and prediction statistics of AL:PE pH model.

\begin{tabular}{llll}
\hline Apparent statistics & & Prediction “jackknife” statistics & \\
\hline RMSE & 0.297 & RMSEP & 0.356 \\
$r^{2}$ & 0.847 & $r^{2}$ & 0.780 \\
Average bias & 0.0005 & Average bias & 0.001 \\
Max. bias & 0.495 & Max. bias & 0.624 \\
\hline
\end{tabular}

from the Hoton-2 core is richer and consists of 294 taxa from 65 genera (Appendix B). Among them 90 taxa identified in this study are new for deep-water lake sediments and 13 taxa are found for the first time in Mongolia. These include Cyclotella operculata var. unipunctata, Amphora dusenii, Brachysira brebissonii, Caloneis tenuis, Cavinula jaernefeltii, C. lacustris, Cymbella behrei, Diploneis domblittensis, Eunotia polydentula, Gomphonema abbreviatum, Luticola undulata, Navicula farta and Stauroneis anceps var. siberica.

The diatom diagram (Fig. 4) has been subdivided into the following five diatom zones (DZ).

DZ 5 (257-205 cm; > 11.5 kyr BP). Diatom concentrations vary between 3.1 and $20.7 \times 10^{6}$ valves/g. The dominant complex is represented by planktonic Cyclotella ocellata and C. bodanica, and Staurosirella pinnata which can be planktonic as well as benthic (Dorofeyuk and Tsetsegmaa, 2002). The lower part of this zone $(257-227.5 \mathrm{~cm})$ is notable for its relatively low concentrations (3.1$13.1 \times 10^{6}$ valves $/ g$ ) and species diversity (31-48 taxa). The dominant species is $C$. ocellata (below $250.5 \mathrm{~cm}$ ) and $C$. bodanica (above $250.5 \mathrm{~cm})$. The uppermost part $(227.5-205 \mathrm{~cm})$ is characterized by an increase in diatom concentrations (4.5-22 $\times 10^{6}$ valves/g) and number of species (58 taxa) and the predominance of $C$. ocellata, C. bodanica and S. pinnata.

DZ 4 (205-172.5 cm; $11.5-10.7 \mathrm{kyr}$ BP) is characterized by the further increase in concentrations up to $69 \times 10^{6}$ valves/g at $185 \mathrm{~cm}$. However, a drop in concentration down to $9 \times 10^{6}$ valves $/ \mathrm{g}$ is recorded in the upper part of the zone. The dominant taxa are C. ocellata, which is abundant in the bottom part of the zone, S. pinnata, which reaches a maximum at $185 \mathrm{~cm}$, and C. bodanica, prevailing in the interval between 209.5 and $191.5 \mathrm{~cm}$. Another notable feature of this zone is the appearance of planktonic Aulacoseira italica, a widespread species in continental mesotrophic and eutrophic waters.

DZ 3 (172.5-72.5 cm; 10.7-6.6 kyr BP) experiences high diatom concentrations $\left(60-81 \times 10^{6}\right.$ valves/g) in the lower part (172.5$140.5 \mathrm{~cm}$; $10.7-9.6 \mathrm{kyr} \mathrm{BP})$. The dominant species is $C$. bodanica (26-43\%) accompanied by S. pinnata. The upper part of this zone demonstrates greater variations in diatom concentrations (28$70 \times 10^{6}$ valves/g) and the predominance of $C$. ocellata and $C$. bodanica.

DZ 2 (72.5-47.5 cm; 6.6-5.6 kyr BP) experiences high diatom concentrations $\left(69-91 \times 10^{6}\right.$ valves/g) and is characterized by the predominance of planktonic A. italica var. italica and A. italica var. tenuissima. C. ocellata and $C$. bodanica are also abundant, but their role becomes less pronounced in this zone.

DZ 1 (47.5-0 cm; 5.6-0 kyr BP) is characterized by the decrease in diatom concentrations down to $23-73 \times 10^{6}$ valves/g. Aulacoseira distans reaches $61 \%$ at $5 \mathrm{~cm}$ depth and together with planktonic $A$. italica, $C$. ocellata, and $C$. bodanica predominates within this zone.

The reconstructed $\mathrm{pH}$ profile (Fig. 4) shows little change throughout the Hoton-2 core, fluctuating between minimum 6.10 $(10 \mathrm{~cm})$ and maximum $7.15(235 \mathrm{~cm})$. There is no sign of either natural or anthropogenic acidification as the lake is well buffered and remote from possible pollution sources. It is likely that the $\mathrm{AL}: \mathrm{PE}$ model slightly underestimates the lake $\mathrm{pH}$, since the measured $\mathrm{pH}$ is about 7.5. Generally, the reconstructed $\mathrm{pH}$ compares well with the reconstructed $\mathrm{pH}$ profile from the Hoton-1 core, with the Hoton-1 record being slightly more acidic.

\section{Interpretation}

\subsection{Vegetation dynamics}

Prior to $11.5 \mathrm{kyr}$ BP very low pollen concentrations and the predominance of NAP taxa well adapted to both dry and cold environments (Fig. 3) suggest a treeless and probably discontinuous vegetation cover around the lake, similar to that of the modern dry steppes and semi-deserts. The early Holocene pollen spectra reveal an increase in pollen concentrations but the pollen composition remains similar to the late Pleistocene phase. Biome reconstruction (Fig. 5a,b) demonstrates that steppe biome scores have the highest values, suggesting the predominance of this vegetation type (Fig. 5c), and scores of taiga and tundra biomes are relatively low between 11.5 and $10.7 \mathrm{kyr}$ BP. Relatively high percentages of Ephedra pollen may as well point to the open character of vegetation and the wide spread of dry steppe and semi-desert communities around the lake.

After $10.7 \mathrm{kyr}$ BP vegetation cover became denser as suggested by the higher pollen concentrations. Both pollen spectra composition and biome reconstruction suggest the spread of trees around the lake from this period onward. One of the main indicators of the local presence of coniferous trees, including Larix and Picea, is the presence of their stomata in the lake sediment (Parshall, 1999; Sweeney, 2004). The finds of Larix stomata are especially important, considering that larch pollen is usually strongly underrepresented in the pollen diagrams (Gunin et al., 1999; Pisaric et al., 2001). Biome reconstruction demonstrates a decrease in steppe scores and an associated increase in taiga scores, suggesting the spread of boreal trees and open woodland vegetation around Hoton-Nur $10-8 \mathrm{kyr}$ BP. The increase in B. sect. Nanae pollen percentages suggests that shrub birches became spread in the sedge-grass alpine belt or/and in the woodland understorey. However, reconstructed tundra scores do not change significantly in comparison with the earlier time interval.

After $7.9 \mathrm{kyr}$ BP the decrease in pollen concentrations and strong variations in the AP and NAP taxa percentages suggest rather unstable environmental conditions and an increased importance of the non-arboreal vegetation in the region. Occurrence of Picea and Larix stomata and relatively high quantities of Picea, Abies, P. sibirica-type and Larix pollen suggest that trees were still well present in the regional vegetation until $5 \mathrm{kyr}$ BP. Relatively high scores of taiga biome supports this interpretation.

From 4.9 kyr BP the greater role of semi-desert and steppe taxa in the pollen spectra indicate a strengthening of these vegetation communities in the area around Hoton-Nur and an associated retreat of the boreal woods to the refugia with slightly better moisture conditions. The reconstruction shows the increase in the steppe biome scores during the past $5 \mathrm{kyr}$ consistent with the qualitative interpretation of the pollen record. Relatively high percentages of coniferous taxa, particularly of $P$. sibirica-type and Picea, in the late Holocene pollen spectra likely indicate their transport from the taiga forests growing in the northern and northwestern parts of the Altai Mountains, rather than the presence of local woods. This interpretation is supported by relatively low pollen concentrations and the disappearance of conifer stomata from the analyzed sediments.

\subsection{Lacustrine environments}

The lower part of the Hoton-Nur core consists of gray-blue clay usually associated with the deep and cold-water oligotrophic lake (Tarasov et al., 1994). Prior to 11.5 kyr PB diatom concentrations are relatively low and the lake is dominated by planktonic Cyclotella and small Fragilariaceae, suggesting a deep and oligotrophic/ mesotrophic lake. Small Fragilariaceae species (e.g. S. pinnata) are 

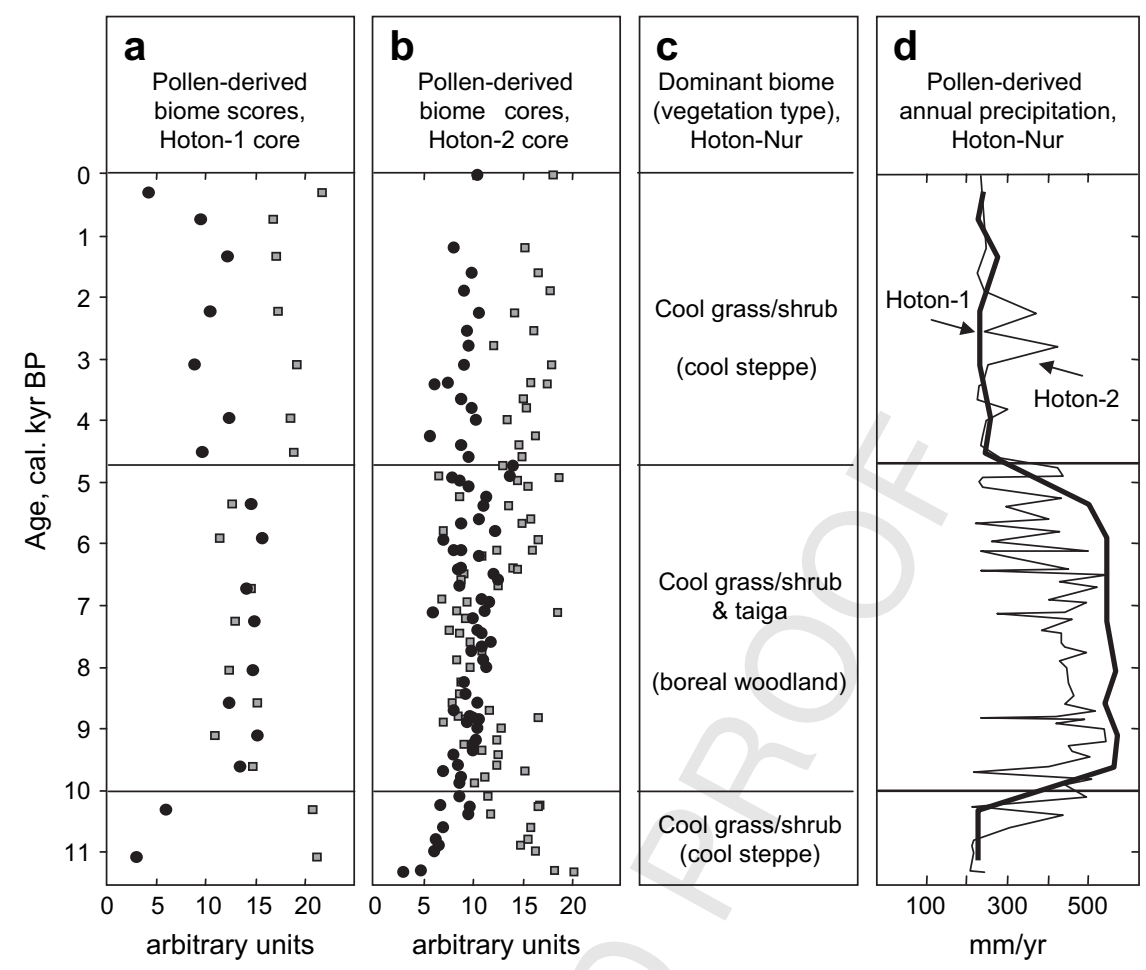

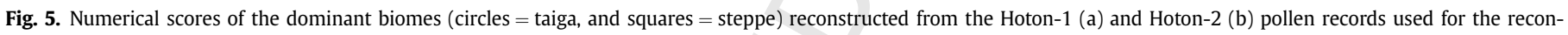
struction of changes in vegetation (c) and annual precipitation (d).

commonly found in disturbed glacial and/or arctic environments (Haworth, 1976; Anderson, 2000). The high abundance of S. pinnata from the beginning of the record until $10.7 \mathrm{kyr}$ BP might imply intensified erosion processes in the catchment and this corresponds well with the presence of scarce and dry vegetation and the generally arid climate during this period. The boundaries of the first two pollen and diatom zones coincide, suggesting the lake ecosystem responded quickly to the changes in the catchment.

From about 10.7 kyr BP, more planktonic diatom taxa appeared and increased in abundance, indicating that the lake diatom flora became more established and diverse. The abundance of small mesotrophic Cyclotella taxa also increased. The lake became more productive as diatom concentration increased. This change correlates well with the development of boreal woodland in the catchment (Fig 6). The decrease in precipitation and changes in the catchment vegetation towards drier steppe are reflected by the rapid increase in $A$. distans from about $5 \mathrm{kyr}$ BP. The ecology of $A$. distans is not entirely clear; it is likely that $A$. distans is either a planktonic or meroplanktonic species, i.e. it spends at least part of its life-cycle in the water column (Turkia and Lepisto, 1999). The increase in $A$. distans coincides with the development of a steppe landscape that is more open and drier than before. Relatively heavy, silicified $A$. distans thrive in lakes with wind-induced turbulence (Ruhland et al., 2003), which is greater in open country than in woodland.

Floristically, the Hoton-Nur Aulacoseira/Cyclotella/Fragilareaceae dominated diatom assemblages are close to deep oligo/mesotrophic lakes located in remote arctic, subarctic and alpine areas of Canada (Rühland et al., 2003; Smol et al., 2005), Scandinavia (Sorvari et al., 2002), and Spain (Catalan et al., 2002). It is likely that the late-Holocene increase in $A$. distans in the lake can be linked to changes in the ice-cover regime as well as the increase in windinduced turbulence due to the vegetation changes in the catchment. The increase in $C$. ocellata in early- to mid-Holocene might also be partially linked to the change in the lake ice-cover regime (e.g. shortening of the ice-cover season) due to the increased humidity. Similar changes in the arctic Scandinavian and Canadian lakes during the 20th century have been attributed to the shortening of the ice cover due to global climate warming (Sorvari et al., 2002; Smol et al., 2005).

Pollen data suggest the late Holocene change in the vegetation cover towards a more open landscape, causing an intensification of the wind and water erosion and a higher risk of wild or anthropogenic fires. Neither diatom nor non-pollen macrofossil analysis of the Hoton-Nur sediment cores provide evidence of significant human impact on the regional environments. Eggs of Macrobiotus, recorded from $8 \mathrm{kyr}$ BP onward, usually indicate unpolluted ecotopes (Jankovska, 1991). Glomus spores, often reported as an indicator of human-influenced soil erosion in the catchment of the lake (van Geel et al., 2003), are found in the Hoton-2 sediment at $\mathbf{0 5}$ extremely low levels of abundance.

\subsection{Climate dynamics}

Pollen and diatom data from Hoton-Nur demonstrate changes in the vegetation and algal communities, which can be interpreted in terms of the past climate dynamics. Both climate-based vegetation modeling (Prentice et al., 1992) and biogeographical studies on the modern vegetation (Gunin et al., 1999) suggest that $T_{\mathrm{c}}, \alpha$ and $P_{\mathrm{ann}}$ are the most relevant climatic parameters for defining boundaries between the principal vegetation types in Mongolia. For example, $T_{\mathrm{C}}=-35^{\circ} \mathrm{C}$ separates cold deciduous forest dominated by Betula and Larix from taiga where boreal deciduous and evergreen coniferous (e.g. Picea, Abies, P. sibirica) taxa can grow together (Prentice et al., 1992). Similarly, $\alpha=0.65$ separates cool steppe from forest biomes. The use of $\alpha$ is limited to the modeling studies, while $P_{\text {ann }}$ is more frequently used in the paleoclimate research based on biological and sedimentary proxies and can be easily compared with meteorological observations and climatic maps. The modern climatic variables at Hoton-Nur (e.g. 0.45 for $\alpha, 250 \mathrm{~mm} / \mathrm{yr}$ for $P_{\text {ann }}$
11

1102 
and $-20^{\circ} \mathrm{C}$ for $T_{\mathrm{C}}$ ) suggest that the modern steppe vegetation around the lake and small isolated woody stands are more sensitive to the moisture parameters, while only a large drop in $T_{\mathrm{c}}$ can destabilize the system. The results of the pollen-based precipitation reconstruction are shown in Fig. 5d. Both Hoton-1 and Hoton-2 records suggest that the regional climate was relatively dry $\left(P_{\text {ann }} \sim 200-300 \mathrm{~mm} / \mathrm{yr}\right.$ and $\left.\alpha \sim 0.3-0.5\right)$ prior to $10 \mathrm{kyr}$ BP. The climate became substantially wetter $\widehat{(P a n n} \sim 300-550 \mathrm{~mm} / \mathrm{yr}$ and $\alpha \sim 0.5-0.8)$ during the following interval between 10 and $5 \mathrm{kyr}$ BP. The onset of a relatively dry climate comparable to the present occurred soon after 5 kyr BP. This climate reconstruction (Fig. 5d) is consistent with the vegetation reconstruction (Fig. 5a-c).

Comparison of the results inferred from the deep-water Hoton2 record with the reconstruction based on the Hoton-1 record obtained from the coastal bay reveals greater pollen/climate variability in the Hoton-2 record (Fig. 5d). For example, during the lateHolocene the climate reconstruction from Hoton-1 demonstrates precipitation values similar to today, while the Hoton- 2 record suggests a $50-100 \mathrm{~mm}$ increase in precipitation between 3 and 2 kyr BP. Another example is several short-term variations in the 
pollen percentages and in the pollen-based reconstructions of biome scores and precipitation values from the Hoton-2 record, particularly during the mid-Holocene humid interval. Observed discrepancies between the Hoton-1 and Hoton-2 records can be explained by (i) larger sample size and lower temporal resolution of the pollen analysis of the Hoton-1 core and/or (ii) a different sampling site location and the various sources of pollen entering it. In a large overflowing lake, pollen spectra from its central deepwater part (Hoton-2) tend to represent a larger region, receiving greater input from regional, rather than local or extra-local vegetation to the pollen assemblages (Jacobson and Bradshaw, 1981). In the Hoton-Nur basin more arid vegetation communities are concentrated at the lower elevations south and east of the lake (Volkova, 1994). Thus, the contribution of the dry taxa to the Hoton2 pollen assemblages is greater in comparison with the Hoton-1, and this is consistent with the reconstruction of generally lower taiga biome scores and precipitation values of the Hoton-2 record (Fig. 5). In several cases during the early and late Holocene the higher taiga scores/precipitation values are derived from the Hoton-2 pollen assemblages with very low pollen concentration (Fig. 3). In latter cases, the reconstruction might be an artefact caused by an increasing role of the long-distant AP transport during the arid intervals characterized by the low local pollen production in the Hoton-2 record (Tarasov et al., 2007b). Overall, the Hoton-1 core collected from a small and relatively closed bay without direct river inflow shows a more stable signal.

\section{Discussion: holocene climatic and environmental changes in Central Asia}

\subsection{Holocene vegetation and climate records from the Altai Mountains and neighboring areas}

Occupying a central position in the mid-latitude Asian interiors, the Altai Mountains resemble a gigantic "T", which splits the area into three characteristic geographical regions: eastern, western and northern. In this section the Holocene vegetation records from these three regions are summarized to facilitate further discussions of the spatial pattern of the Holocene climate and its background mechanisms.

\subsubsection{Eastern Region (ER): the Mongolian Altai}

The Hoton-1 and Hoton-2 records demonstrate generally parallel changes in the reconstructed environments (Fig. 5), suggesting that the area was characterized by a relatively dry climate and cool steppe vegetation prior to $10 \mathrm{kyr}$ BP. Generally wetter than present conditions occurred between 10 and $5 \mathrm{kyr}$ BP causing a spread of boreal trees. The re-establishment of steppe as a dominant vegetation type was associated with a significant decrease in atmospheric precipitation after $5 \mathrm{kyr}$ BP. Other vegetation records from the ER are in line with this reconstruction. For example, the pollen data from Achit-Nur $\left(49^{\circ} 30^{\prime} \mathrm{N}, 90^{\circ} 36^{\prime} \mathrm{E}\right.$, 1435 m, Fig. 1) demonstrate a quick increase in AP from less than 5\% prior to $10.5 \mathrm{kyr}$ BP to $35-50 \%$ between 10 and $5 \mathrm{kyr}$ BP (Gunin et al., 1999), suggesting a wetter than present mid-Holocene climate and open woodland vegetation. The "Kharkhiraa south side” pollen record $\left(49^{\circ} 26^{\prime} \mathrm{N}, 91^{\circ} 15^{\prime} \mathrm{E}, 2570 \mathrm{~m}\right.$, Fig. 1) provides further proof of humid conditions between 10.6 and $5.3 \mathrm{kyr}$ BP and dry vegetation and climate during the earlier and later periods (Schlütz, 2000). The palynological study of the Bayan Nuur $\left(50^{\circ} 00^{\prime} \mathrm{N}, 93^{\circ} 58^{\prime} \mathrm{E}, 932 \mathrm{~m}\right.$, Fig. 1) core also suggests a phase of higher humidity during the middle Holocene, as indicated by the highest AP percentages between 10 and 6.9 kyr BP (Krengel, 2000; Grunert et al., 2000). Radiocarbon dating of numerous Picea, Abies and Larix wood fragments identified in peat deposits from BayanSair $\left(47.75^{\circ} \mathrm{N}, 96.91^{\circ} \mathrm{E}, 2600 \mathrm{~m}\right.$, Fig. 1) proves the disappearance of spruce and fir from the local vegetation between 5 and $3.8 \mathrm{kyr}$ BP, while larch was present until $3 \mathrm{kyr}$ BP (Gunin et al., 1999). The midHolocene presence of taiga woods in the southern Mongolian Altai would require $P_{\text {ann }}$ to be $\sim 100-150 \mathrm{~mm} / \mathrm{yr}$ higher than present (Tarasov et al., 2000).

\subsubsection{Western Region (WR): the Kazakh Upland}

Pollen records from Ozerki Swamp $\left(50^{\circ} 24^{\prime} \mathrm{N}, 80^{\circ} 28^{\prime} \mathrm{E}, 210 \mathrm{~m}\right.$, Fig. 1$)$ in the Irtysh River valley and from Pashennoe Lake $\left(49^{\circ} 22^{\prime} \mathrm{N}\right.$, $75^{\circ} 24^{\prime} \mathrm{E}, 871 \mathrm{~m}$, Fig. 1 ) in the Karkaraly Mountains (Kremenetski et al., 1997; Tarasov et al., 1997) reveal the high percentages of steppe- and desert-associated herbaceous taxa throughout the late glacial, early and middle Holocene. The Ozerki pollen record suggests a local presence of the riparian birch forests in the Irtysh River valley around $8.5 \mathrm{kyr}$ BP. However, the encroachment of the pine forests into the Kazakhstan steppe became a distinctive feature of the second half of the Holocene. Pollen records from lakes Mokhovoe $\left(53^{\circ} 46^{\prime} \mathrm{N}, 64^{\circ} 15^{\prime} \mathrm{E}\right)$ and Karasye $\left(53^{\circ} 02^{\prime} \mathrm{N}, 70^{\circ} 13^{\prime} \mathrm{E}\right)$ situated in northern Kazakhstan (Kremenetski et al., 1997; Tarasov et al., 1997) suggest that the pine-dominated island forests were established in the northern part of the WR about $6 \mathrm{kyr}$ ago and then spread southwards. Around remotely located Lake Pashennoe (Fig. 1) the forest apparently reached its maximum spread only during the last millennium (Tarasov et al., 2007b).

\subsubsection{Northern Region (NR): the Russian Altai}

The pollen records from the Ulagan Plateau $\left(50^{\circ} 27^{\prime}-50^{\circ} 30^{\prime} \mathrm{N}\right.$, $87^{\circ} 06^{\prime}-87^{\circ} 40^{\prime} \mathrm{E}, 1985-2150 \mathrm{~m}$, Fig. 1) suggest that the trees appeared in the area from $12 \mathrm{kyr}$ BP (Blyakharchuk et al., 2004). However, the full expansion of the evergreen boreal coniferous forests occurred rapidly only after $10 \mathrm{kyr}$ BP. The role of Picea and Abies in these forests decreased by about $7.5 \mathrm{kyr} \mathrm{BP}$ and the vegetation cover has changed very little since that time until today. The pollen records from lower elevation Dzhangyskol $\left(50^{\circ} 11^{\prime} \mathrm{N}\right.$, $87^{\circ} 44^{\prime} \mathrm{E}, \sim 1800 \mathrm{~m}$ ) also suggest spread of woods after $11 \mathrm{kyr} \mathrm{BP}$ (Blyakharchuk et al., 2008). However, maximal expansion of boreal forests in the area coincides with the highest lake levels in Dzhangyskol during the late Holocene. By contrast to the western area, the pollen records from Tuva $\left(50^{\circ} 15^{\prime}-50^{\circ} 16^{\prime} \mathrm{N}, 89^{\circ} 27^{\prime}-\right.$ $89^{\circ} 37^{\prime} \mathrm{E}, 2204-2413 \mathrm{~m}$, Fig. 1) located in the relatively dry eastern part of the NR indicate the taiga development in response to increased humidity between 11 and $6 \mathrm{kyr} \mathrm{BP}$, and a shift to a drier climate similar to present after 6 kyr BP (Blyakharchuk et al., 2007).

\subsection{Mechanisms driving the Holocene vegetation and climate dynamics in Central Asia}

The records summarized in Section 6.1 demonstrate spatially variable Holocene vegetation and climate histories in the large area of Central Asia separated by the main watersheds of the Altai Mountains into three well-defined geographical regions. The recorded regional differences imply different driving mechanisms of the post-glacial environmental dynamics and encourage a search for those mechanisms.

Great distances separate the Altai Mountains from all the oceans and thus from the main sources of precipitation in the Eurasian mid-latitudes. The present-day precipitation and plant-available moisture in the WR is mainly controlled by cyclonic advections from the Atlantic Ocean (Alpat'ev et al., 1976; Martyn, 1992). However, the ER bordered from the west by the Altai Mountains stays in the rain shadow. In eastern Asia, the modern precipitation pattern is controlled by the summer monsoon transporting moisture from the Pacific Ocean (Domrös and Peng, 1988). The modern limit of the summer monsoon is commonly placed along the eastern border of Mongolia and as far as the eastern parts of the Tibetan Plateau (Winkler and Wang, 1993; Wei and Gasse, 1999). 
However, meteorological observations suggest that in the Mongolian Altai incursions of Pacific air masses amplified by the mountain relief are responsible for the precipitation during the warm season (Tarasov et al., 2000). In the NR, precipitation is controlled by western and northwestern cyclones bringing warm and moist air during the summer season (Alpat'ev et al., 1976). In winter, very cold, sunny and predominantly dry weather caused by the Siberian anticyclone prevails in all the discussed regions of Central Asia (Martyn, 1992).

Vegetation and climate reconstructions for the ER have been interpreted as evidence of the early-middle Holocene strengthening of the summer monsoon (Harrison et al., 1996; Tarasov et al., 2000). The study on oxygen isotopes in lacustrine sediments from western and northwestern China (Wei and Gasse, 1999) suggested, for its part, that the Pacific monsoon did influence northwestern China between 11 and 4.5/3.5 kyr BP and provided constantly high precipitation in northeastern and central Tibet 11-8 kyr BP (Wei and Gasse, 1999). Prior to $11 \mathrm{kyr}$ BP desert-like environments are reconstructed around Lake Manas $\left(45^{\circ} 45^{\prime} \mathrm{N}, 86^{\circ} 00^{\prime} \mathrm{E}\right.$, Fig. 1) followed by a 3 kyr episode when the lake became fresh and deep and steppe vegetation grew around it (Rhodes et al., 1996). The $\delta^{18} \mathrm{O}$ record from Manas correlates very well with the environmental reconstructions for the Mongolian Altai presented in this study, suggesting the same mechanism for the early- to mid-Holocene increase in precipitation.

The early- to mid-Holocene monsoon-associated increase in summer rainfall in the upper Irtysh River, which originated from northwestern China, may well account for the local development of the riparian birch forests in the Irtysh River valley around $8.5 \mathrm{kyr} \mathrm{BP}$, as seen in the Ozerki pollen diagram (Kremenetski et al., 1997; Tarasov et al., 1997), but not in the other records from Kazakhstan situated beyond the range of Irtysh influence. By contrast to the ER (Fig. 6g), the first half of the Holocene was drier than at present in the WR, where a shift towards wetter conditions did not occur until $7 \mathrm{kyr}$ BP. The late Holocene spread of pine and birch forests in northern and central Kazakhstan (Fig. 6e), indicating an increase in precipitation or a decrease in evaporation losses, has been noted (Kremenetski et al., 1997; Tarasov et al., 1997). Recently it was suggested (Tarasov et al., 2007b) that both the movement of Atlantic air masses driven by a northward shift in westerly flow, and the efficiency of advective water recycling during moisture transport to the Asian interiors, may be responsible for the late Holocene improvement of the regional water balance. The late Quaternary lake-status (Harrison et al., 1996) and isotope (Bar-Matthews and Ayalon, 2004) records demonstrate that the Mediterranean region, which at present receives precipitation associated with the winter westerlies, became drier than before after $6 \mathrm{kyr} \mathrm{BP}$, while the region of northern Europe experienced a shift towards wetter conditions after $5 \mathrm{kyr}$ BP and most of the analyzed lakes there reached the highest levels during the last millennia (Harrison et al., 1996; Barber et al., 2004; Snowball et al., 2004). Wohlfarth et al. (2006) also demonstrated that the lakes in the central Russian Plain, recently controlled by the westerly through most of the year, experienced very low levels between 13 and $5.5 \mathrm{kyr}$ BP, before turning to more humid conditions after that (Fig. 6d).

The present-day atmospheric circulation and precipitation regime of the WR (including Kazakhstan) resemble those of northern and eastern Europe (Martyn, 1992). Taking into account a similarity in the reconstructed Holocene changes in the regional precipitation/water budgets we assume that they have the same background mechanism. The transition from warm and dry early and middle Holocene to cool and wet late-Holocene in western Eurasian mid-latitudes was explained by declining summer insolation (Fig. 6a), the cooling of Arctic waters (Fig. 6c) and reduced summer temperatures/evaporation (Snowball et al., 2004). A parallel increase in winter insolation and sea level rise (Fig. 6b) indicating a decrease in the global ice volume (Peltier and Fairbanks, 2006) could also play an important role, as it might be responsible for the weakening of the winter monsoon in Siberia, which then allowed farther eastward penetration of the relatively warm and wet Atlantic air masses. This process was complicated by a number of regional factors, which could be responsible for a highly meridional circulation pattern over Europe during the first half of the Holocene in comparison to a zonal circulation pattern observed today (Harrison et al., 1996).

The pollen records from the NR (Fig. 6f) show the humidity/ precipitation pattern, which makes it similar to the ER before 6 kyr BP and to the WR after that. Ilyashuk and Ilyashuk (2007), using chironomid and lithology records and results of the diatom analysis (Westover et al., 2006), suggested that the Pacific monsoon brought precipitation to the Russian Altai in the early Holocene, whereas cyclones associated with the Atlantic westerlies were likely responsible for the moisture transport during the second half of the Holocene. The reconstructed mid-Holocene phase of relatively dry climatic conditions falls in an interval when a major transformation of the atmospheric circulation occurred in Eurasia. During this period the attenuation of the Pacific monsoon circulation and the retreat of the summer monsoon front documented in the records from western Mongolia and north-western China caused a reduction of precipitation in the Russian Altai, whereas the Atlantic influence in the NR, as proved independently by the evidence from Kazakhstan and Russia. A comparison between the pollen/vegetation/climate records from the western (e.g. Ulagan, Dzhangyskol) and eastern part (Tuva) of the NR demonstrates that both areas had two precipitation maxima. However, the early Holocene (summer monsoon-associated) maximum was more pronounced in the eastern part, and the late Holocene (westerlyassociated) maximum could be better seen in the western part of the NR, in line with the records from Kazakhstan and Mongolia.

\subsection{Holocene vegetation dynamics in the Mongolian Altai: climate change or human activities?}

The interpretation of changes in AP content in terms of climate is not unambiguous, since the forest degradation and associated changes in the pollen assemblages can be also explained by human activities. Thus, pollen-based climatic inferences benefit from additional evidence from independent proxies. Changes in the moisture balance reconstructed from 11 Mongolian lakes (Tarasov et al., 1996; Walter et al., 2003) closely resemble the pollen-based climate reconstruction (Fig. 6g), and support the assumption that the vegetation dynamics reconstructed from the Hoton-Nur record are primarily driven by the changes in precipitation.

Archaeological records, e.g. a great number of petroglyphic images and ritual structures in the river valleys of Tsagaan Salaa and Baga Oigor $\left(49^{\circ} 25^{\prime} \mathrm{N}, 88^{\circ} 15^{\prime} \mathrm{E}, \sim 2350-2650 \mathrm{~m}\right)$ situated $75 \mathrm{~km}$ north of Hoton-Nur, suggest more or less continuous habitation of the Mongolian Altai since $12 \mathrm{kyr}$ BP (Jacobson, 2001). Small communities subsisting on hunting of forest- and steppe-associated animals, fishing and gathering were present in the region prior to 4 kyr BP. The number of images of forest animals (e.g. bear, true dear and elk) decreases after 4 kyr BP and images of wild boar, an inhabitant of the riparian forests and shrubs, and wild yak, preferring open steppe landscapes, become more important in line with our environmental reconstruction (Fig. 5). The emergence of mounted pastoralism after $3 \mathrm{kyr} \mathrm{BP}$ concluded the transition from a hunting-gathering economy to a nomadic or semi-nomadic pastoral economy in the Mongolian Altai (Jacobson, 2001). Wood of coniferous trees (mainly Larix) was commonly used to construct tomb chambers during 2.9-2 kyr BP (Parzinger, 2006; Heussner and Sljusarenko, 2007), e.g. only after the main transformation 
from woodland to steppe was completed as the result of the climate change towards aridity. It is possible that the disappearance of Larix from the Gobi Altai after 3 kyr BP (Gunin et al., 1999; Miehe et al., 2007) was initially triggered by climate change and then aggravated by human activities under conditions unsuitable for tree re-growth. However, the absence of diagnostic anthropogenic indicators in the Hoton-Nur pollen and diatom records indicates that human disturbance of soils and vegetation cover was less significant than might have been expected. Our conclusion is consistent with the recent results from the Khentey Mountains $\left(49^{\circ} 04^{\prime} 48^{\prime \prime} \mathrm{N}, 107^{\circ} 17^{\prime} 15^{\prime \prime} \mathrm{E}, 900-1600 \mathrm{~m}\right.$, Schlütz et al., 2008), where the absence of charcoal and other anthropogenic indicators in the palynological records until modern times imply that the steppe islands are of natural origin and not a replacement of the former taiga due to burning or grazing.

\section{Conclusions}

1. A quantitative reconstruction of Holocene vegetation and climate dynamics was inferred from the Hoton-Nur records from the semiarid Mongolian Altai. Our reconstruction suggests a rapid forestation in the primarily open landscape of northwestern Mongolia after $10 \mathrm{kyr} \mathrm{BP}$ in response to a noticeable increase in precipitation from $200-250 \mathrm{~mm} / \mathrm{yr}$ to $450-550 \mathrm{~mm} / \mathrm{yr}$. A return to a predominance of open vegetation types occurred after $5 \mathrm{kyr} \mathrm{BP}$ when precipitation decreased to modern values of $250-300 \mathrm{~mm} / \mathrm{yr}$.

2. This reconstruction is in agreement with the $\delta^{18} \mathrm{O}$ records from China, demonstrating an abrupt strengthening of the monsoon in the early Holocene and an associated increase in precipitation and in lake levels in northwestern China between 11 and $8 \mathrm{kyr} \mathrm{BP}$, followed by the stepwise attenuation of the monsoon circulation and climate aridization towards the modern level between 8 and 4.5/3.5 kyr BP.

3. Occupying a central position in the mid-latitude Asian interiors, the Altai Mountains resemble a gigantic " $T$ ", which splits the area into three characteristic geographical regions: eastern (ER), western (WR) and northern (NR). Comparisons of records from the Mongolian Altai (ER), the Kazakh Upland (WR) and the Russian Altai (NR) reveal spatially and temporally different Holocene vegetation and climate histories.

4. During the first half of the Holocene the WR was drier than present whereas the ER was moister than present. A shift towards wetter conditions occurred in the WR only during the second half of the Holocene, when the mid-latitudinal belt, stretching from the Baltic Sea to northern Kazakhstan and southern Siberia, came under the control of the Atlantic air masses. At the same time conditions in the ER became dry. Productivity of the steppes shifted from east to west at about $3 \mathrm{kyr}$ BP, so migration movements of animal-keeping human communities proved by archaeological and historical records are the logical consequence.

5. The pollen/vegetation/climate records from the NR, however, display two precipitation maxima during past $12 \mathrm{kyr}$ BP. While the early Holocene (summer monsoon-associated) maximum was more pronounced in the eastern part of the region, the late Holocene (westerly-associated) maximum could be better seen in the western part, in line with the records from the ER and WR, respectively.

6. Despite the more or less permanent presence of humans in the Mongolian Altai since the early Holocene, the absence of diagnostic anthropogenic indicators in the Hoton-Nur pollen and diatom records indicates that human disturbance of soils and vegetation cover was less significant than might have been expected. The emergence of mounted pastoralism after 3 kyr BP and well-documented use of wood to construct tomb chambers in the NR (2.9-2 kyr BP) occurred only after the main transformation from woodland to steppe in the ER was completed as the result of the climate change towards aridity.

\section{Uncited references}

Berger and Loutre, 1991; Birks and Koç, 2002; Schlütz and Lehmkuhl, 2007; Tarasov and Harrison, 1998; Yuan et al., 2004.

\section{Acknowledgments}

The paper is a contribution to the DFG-sponsored Program "Interdynamik" (Ref. TA 540/1). N.R. was supported by the DAAD (Ref. 325, A/05/00162), INTAS Young Scientist Fellowship (Ref. 061000014-5781), the Russian Foundation for Basic Research (grants 08-05-00773 and 06-05-64931) and by the Russian Academy of Sciences, Siberian Branch (Project Nr. 108). We are grateful to V. Jankovska, L. Nazarova and A. Ebel for consultations; to T. Semina and N. Gorban for cartographic assistance; and to N. Roberts and two anonymous reviewers for valuable comments.

\section{Appendix B. Supplementary data}

Supplementary information for this manuscript can be found in the online version, at doi:10.1016/j.quascirev.2008.10.013.

\section{References}

Alpat'ev, A.M., Arkhangel'skii, A.M., Podoplelov, N.Y., Stepanov, A.Y., 1976. Fizicheskaya geografiya SSSR (Aziatskaya chast'). Vysshaya Shkola, Moscow (in Russian).

Anderson, N.J., 2000. Diatoms, temperature and climatic change. European Journal of Phycology 35, 307-314.

Barber, K., Zolitschka, B., Tarasov, P., Lotter, A.F., 2004. Atlantic to Urals-the Holocene climatic record of Mid-Latitude Europe. In: Battarbee, R.W., Gasse, F., Stickley, C.E. (Eds.), Past Climate Variability through Europe and Africa. Developments in Paleoenvironmental Research, Vol. 6. Springer, Dordrecht, pp. 417-442.

Bar-Matthews, M., Ayalon, A., 2004. Speleothems as palaeoclimate indicators, a case study from Soreq cave located in the eastern Mediterranean region, Israel. In: Battarbee, R.W., Gasse, F., Stickley, C.E. (Eds.), Past Climate Variability through Europe and Africa. Developments in Paleoenvironmental Research, Vol. 6. Springer, Dordrecht, pp. 363-391.

Battarbee, R.W., 1986. Diatom analysis. In: Berglund, B.E. (Ed.), Handbook of Holocene Palaeoecology and Palaeohydrology. Wiley, Chichester, pp. 527-570.

Berger, A., Loutre, M.F., 1991. Insolation values for the climate of the last 10,000,000 years. Quaternary Science Reviews 10, 297-317.

Birks, C.J.A., Koç, N., 2002. A high-resolution diatom record of late-Quaternary sea-surface temperatures and oceanographic conditions from the eastern Norwegian Sea. Boreas 31, 323-344.

Blyakharchuk, T.A., Wright, H.E., Borodavko, P.S., van der Knaap, W.O., Ammann, B., 2004. Late-glacial and Holocene vegetational changes on the Ulagan high-mountain plateau, Altai Mountains, southern Siberia. Palaeogeography, Palaeoclimatology, Palaeoecology 209, 259-279.

Blyakharchuk, T.A., Wright, H.E., Borodavko, P.S., van der Knaap, W.O., Ammann, B., 2007. Late Glacial and Holocene vegetational history of the Altai Mountains (southwestern Tuva Republic, Siberia). Palaeogeography, Palaeoclimatology, Palaeoecology 245, 518-534.

Blyakharchuk, T.A., Wright, H.E., Borodavko, P.S., van der Knaap, W.O., Ammann, B., 2008. The role of Pingos in the development of the Dzhangyskol lake-Pingo complex, central Altai Mountains, Southern Siberia. Palaeogeography, Palaeoclimatology, Palaeoecology 254 (4), 404-420.

Cameron, N.G., Birks, H.J.B., Jones, V.J., Berge, F., Catalan, J., Flower, R.J., Garcia, J., Kawecka, B., Koinig, K.A., Marchetto, A., Sanchez-Castillo, P., Schmidt, R. Sisko, M., Solovieva, N., Stefkova, E., Toro, M., 1999. Surface-sediment and epilithic diatom $\mathrm{pH}$ calibration sets for remote European mountain lakes (AL: PE Project) and their comparison with the Surface Waters Acidification Programme (SWAP) calibration set. Journal of Paleolimnology 22, 291-317.

Catalan, J., Pla, S., Rieradevall, M., Felip, M., Ventura, M., Buchaca, T., Camarero, L., Brancelj, A., Appleby, P.G., Lami, A., Grytnes, J.A., Agustí-Panareda, A., Thompson, R., 2002. Lake Redó ecosystem response to an increasing warming in the Pyrenees during the twentieth century. Journal of Paleolimnology 28, 129-145.

Davydova, N.N., 1985. Diatomovue vodorosli-indikatory prirodnykh uslovii vodoemov v golotsene. Nauka, Leningrad (in Russian).

Domrös, M., Peng, G., 1988. The Climate of China. Springer, Heidelberg. 
Dorofeyuk, N.I., Tsetsegmaa, D., 2002. Conspectus of algae flora of Mongolia. Nauka, Moscow (in Russian).

Ecosystems of Mongolia. Atlas, 2005. Nauka, Moscow.

Faegri, K., Iversen, J., 1989. Textbook of Pollen Analysis. John Wiley \& Sons, Chichester.

Fowell, S.J.B., Hansen, C.S., Peck, J.A., Khosbayar, P., Ganbold, E., 2003. Mid to late Holocene climate evolution of the Lake Telmen Basin, North Central Mongolia, based on palynological data. Quaternary Research 59, 353-363.

Grimm, E., 1987. CONISS: A FORTRAN 77 program for stratigraphically constrained cluster analysis by the methods of incremental sum of squares. Computers \& Geoscience 13, 13-15.

Grimm, E., 1991. TILIA and TILIAGRAPH, Springfield, IL.

Grunert, J., Lehmkuhl, F., Walther, M., 2000. Paleoclimatic evolution of the Uvs Nuur basin and adjacent areas (Western Mongolia). Quaternary International 65/66, $171-191$.

Guiot, J., 1990. Methodology of the last climatic cycle reconstruction from pollen data. Palaeogeography, Palaeoclimatology, Palaeoecology 80, 49-69.

Gunin, P.D., Vostokova, E.A., Dorofeyuk, N.I., Tarasov, P.E., Black, C.C. (Eds.), 1999. Vegetation Dynamics of Mongolia. Kluwer Academic Publishers, Dordrecht.

Harrison, S., Yu, G., Tarasov, P., 1996. Late Quaternary lake-level record from Northern Eurasia. Quaternary Research 45, 138-159.

Haworth, E.Y., 1976. Two late-glacial (Late Devensian) diatom assemblage profiles from northern Scotland. New Phytologist 77, 227-256.

Heussner, K.-U., Sljusarenko, I., 2007. Die Dendrochronologie von Aržan 2. In: Menghin, W., Parzinger, H., Nagler, A., Nawroth, M. (Eds.), Im Zeichen des goldenen Greifen. Königsgräber der Skythen. Prestel, Berlin, pp. 83-84. 2007.

Ilyashuk, B., Ilyashuk, E., 2007. Chironomid record of Late Quaternary climatic and environmental changes from two sites in Central Asia (Tuva Republic, Russia)-local, regional or global causes? Quaternary Science Reviews 26, 705-731.

Jacobson, E., 2001. Tsagaan Salaa/Baga Oigor: The physical content and palaeoenvironmental considerations. In: Jacobson, E., Kubarev, V., Tseevendorj, D. (Eds.), Répertoire des pétroglyphes D’Asie Centrale. Mémoires de la Mission Archéologique Française en Asie Centrale, Vol. 6. De Boccard, Paris, pp. 7-15.

Jankovska, V., 1991. Unbekannte Objekte in Pollenpräparaten-Tardigrada. Proc.. of the Pan-European Palaeobot. Conf. Vienna, Austria, pp. 19-23.

Komarek, J., Jankovska, V., 2001. Review of the Green Algal Genus Pediastrum; Implication for Pollen-Analytical Research. Bibliotheca Phycologica. Band 108, Berlin, Stuttgart

Krammer, K., Lange-Bertalot, H., 1986-1991. Bacillariophyceae. Gustav Fisher Verlag, Stuttgart.

Kremenetski, V., Tarasov, P., Cherkinsky, E., 1997. Postglacial development of Kazakhstan pine forests. Geographie physique et Quaternaire 51, 391-404.

Krengel, M., 2000. Discourse on history of vegetation and climate in Mongolia-palynological report of sediment core Bayan Nuur I (NW-Mongolia). Berliner geowissenschaftliche Abhandlungen A 205, 80-84.

Kuprianova, L.A., Alyoshina, L.A., 1972. Pyl'za i spory rastenii flory Evropeiskoi chasti SSSR. Nauka, Leningrad (in Russian).

Leemans, R., Cramer, W., 1991. The IIASA climate database for mean monthly values of temperature, precipitation and cloudiness on a global terrestrial grid, RR-9118. International Institute of Applied Systems Analysis, Luxemburg.

Martyn, D., 1992. Climates of the World. Developments in Atmospheric Sciences 18. Elsevier, Amsterdam.

Miehe, G., Schlütz, F., Miehe, S., Opgenoorth, L., Cermak, J., Samiya, R., Jäger, E.J., Wesche, K., 2007. Mountain forest islands and Holocene environmental changes in Central Asia: A case study from the southern Gobi Altay, Mongolia. Palaeogeography, Palaeoclimatology, Palaeoecology 250 (1-4), 150-166.

Nakagawa, T., Tarasov, P., Kotoba, N., Gotanda, K., Yasuda, Y., 2002. Quantitative pollen-based climate reconstruction in Japan: application to surface and late Quaternary spectra. Quaternary Science Reviews 21, 2099-2113.

National Atlas, 1990. National Atlas of Mongolian People's Republic. Ulan-Bator Moscow (in Russian).

Ogureeva, G.N., 1980. Botanichaskaya Geographiya Altaya. Nauka, Moscow (in Russian).

Overpeck, J.T., Webb III, T., Prentice, I.C. 1985. Quantitative interpretation of fossil pollen spectra, dissimilarity coefficients and the method of modern analogs. Quaternary Research 23, 87-108.

Parshall, T., 1999. Documenting forest stand invasion: fossil stomata and pollen in forest hollows. Canadian Journal of Botany 77, 1529-1538.

Parzinger, H., 2006. Die frühen Völker Eurasiens vom Neolithikum bis zum Mittelalter. Verlag C.H. Beck, München.

Peck, J., Khosbayar, P., Fowell, S., Pearce, R., Ariunbileg, S., Hansen, B. Soninkhishig, N., 2002. Mid to Late Holocene climate change in north central Mongolia as recorded in the sediments of Lake Telmen. Palaeogeography, Palaeoclimatology, Palaeoecology 183, 135-153.

Peltier, W.R., Fairbanks, R.G., 2006. Global glacial ice volume and Last Glacial Maximum duration from an extended Barbados sea level record. Quaternary Science Reviews 25, 3322-3337.

Pisaric, M.F.J., MacDonald, G.M., Cwynar, L.C., Velichko, A.A., 2001. Modern pollen and conifer stomates from north-central Siberian lake sediments: their use in interpreting late Quaternary fossil pollen assemblages. Arctic, Antarctic and Alpine Research 33, 19-27.

Prentice, I.C., Crameer, W., Harrison, S.P., Leemans, R., Monserud, R.A., Solomon, A.M., 1992. A global biome model based on plant physiology and dominance, soil properties, and climate. Journal of Biogeography 19, 117-134.
Prentice, I.C., Guiot, J., Huntley, B., Jolly, D., Cheddadi, R., 1996. Reconstructing biomes from palaeoecological data: a general method and its application to European pollen data at 0 and 6 ka. Climate Dynamics 12, 185-194.

Prentice, I.C., Jolly, D., BIOME 6000 participants, 2000. Mid-Holocene and glacialmaximum vegetation geography of the northern continents and Africa. Journal of Biogeography 27, 507-519.

Prokopenko, A., Khursevich, G., Bezrukova, E., Kuzmin, M., Boes, X., Williams, D. Fedenya, S., Kulagina, N., Letunova, P., Abzaeva, A., 2007. Paleoenvironmental proxy records from Lake Hovsgol, Mongolia, and a synthesis of Holocene climate change in the Lake Baikal watershed. Quaternary Research 68, 2-17.

Reille, M., 1992. Pollen et Spores d'Europe et d'Afrique du Nord. Laboratoire de Botanique Historique et Palynologie. URA CNRS, Marseille, France.

Reille, M., 1998. Pollen et spores d'Europe et d'Afrique du nord. Supplément 2. Laboratoire de botanique historique et palynologie. URA CNRS, Marseille France.

Rhodes, T.E., Gasse, F., Lin, R., Fontes, J.-C., Wie, K., Bertrand, P., Gibert, E. Melie'res, F., Tucholka, P., Wang, Z., Cheng, Z., 1996. A Late Pleistocene-Holocene lacustrine record from Lake Manas, Zunggar (northern Xinjiang, western China). Palaeogeography, Palaeoclimatology, Palaeoecology 120, 105-121.

Rühland, K.M., Smol, J.P., Pienitz, R., 2003. Ecology and spatial distributions of surface-sediment diatoms from 77 lakes in the subarctic Canadian treeline region. Canadian Journal of Botany 81, 57-73.

Schlütz, F., 2000. Palynological investigations in the Turgen-Kharkhiraa mountains, Mongolian Altay. Berliner geowissenschaftliche Abhandlungen A 205, 85-90.

Schlütz, F., Lehmkuhl, F., 2007. Climatic change in the Russian Altai, southern Siberia, based on palynological and geomorphological results, with implications for climatic teleconnections and human history since the middle Holocene. Vegetation History and Archaeobotany 16, 101-118.

Schlütz, F., Dulamsuren, C., Wieckowska, M., Mühlenberg, M., Hauck, M., 2008. Late Holocene vegetation history suggests natural origin of steppes in the northern Mongolian mountain taiga. Palaeogeography, Palaeoclimatology, Palaeoecology 261, 203-217.

Schrader, H.-J., 1974. Proposal for a standardized method of cleaning diatombearing deep sea and land-exposed marine sediments. Nowa Hedwigia 45, 403-409.

Smittenberg, R.H., Baas, M., Schouten, S., Sinninghe Damste, J.S., 2005. The demise of the alga Botryococcus braunii from a Norwegian fjord was due to early eutrophication. The Holocene 15, 133-140.

Smol, J.P., Wolfe, A.P., Birks, H.J.B., Douglas, M.S.V., Jones, V., Korhola, A., Pienitz, R., Ruhland, K., Sorvari, S., Antoniades, D., Brooks, S., Fallu, M.-A., Hughes, M., Keatley, B., Laing, T., Michelutti, N., Nazarova, L., Nyman, M., Quinlan, R. Paterson, A., Perren, B., Rautio, M., Saulnier-Talbot, E., Siitonen, S., Solovieva, N. Weckström, J., 2005. Climate-driven regime shifts in the 845 biological communities of arctic lakes. Proceedings of the National Academy of Sciences USA 102, 4397-4402.

Snowball, J., Korhola, A., Briffa, K.R., Koç, N., 2004. Holocene climate dynamics in Fennoscandia and the North Atlantic. In: Battarbee, R.W., Gasse, F., Stickley, C.E. (Eds.), Past Climate Variability through Europe and Africa. Developments in Paleoenvironmental Research, Vol. 6. Springer, Dordrecht, pp. 465-494.

Solovieva, N., Tarasov, P., MacDonald, G., 2005. Quantitative reconstruction of Holocene climate from Chuna Lake pollen record, Kola Peninsula, north-west Russia. The Holocene 15 (1), 141-148.

Sorvari, S., Korhola, A., Thompson, R., 2002. Lake diatom response to recent Arctic warming in Finnish Lapland. Global Change Biology 8, 171-181.

Sweeney, Ch., 2004. A key for the identification of stomata of the native conifers of Scandinavia. Review of Palaeobotany and Palynology 128, 281-290.

Tarasov, P., Harrison, S., 1998. Lake status records from the Former Soviet Union and Mongolia: a continental-scale synthesis. Paläoklimaforschung 25, 115-130.

Tarasov, P.E., Harrison, S.P., Saarse, L., Pushenko, M.Ya., Andreev, A.A., Aleshinskaya, Z.V. Davydova, N.N., Dorofeyuk, N.I., Efremov, Yu.V., Khomutova, V.I., Sevastyanov, D.V. Tamosaitis, J., Uspenskaya, O.N., Yakushko, O.F., Tarasova, I.V., 1994. Lake status records from the former Soviet Union and Mongolia: data base documentation. NOAA Palaeoclimatology Publications Series Report No. 2, Boulder.

Tarasov, P.E., Pushenko, M.Ya., Harrison, S.P., Saarse, L., Andreev, A.A. Aleshinskaya, Z.V., Davydova, N.N., Dorofeyuk, N.I., Efremov, Yu.V., Elina, G.A. Elovicheva, Ya.K., Filimonova, L.V., Gunova, V.S., Khomutova, V.I., Kvavadze, E.V., Neustrueva, I.Yu., Pisareva, V.V., Sevastyanov, D.V., Shelekhova, T.S. Subetto, D.A., Uspenskaya, O.N., Zernitskaya, V.P., 1996. Lake Status Records from the Former Soviet Union and Mongolia: Documentation of the Second Version of the Data Base. NOAA Paleoclimatology Publications Series Report No. 5 , Boulder.

Tarasov, P., Jolly, D., Kaplan, J., 1997. A continuous Late Glacial and Holocene record of vegetation changes in Kazakhstan. Palaeogeography, Palaeoclimatology, Palaeoecology 136, 281-292.

Tarasov, P.E., Webb III, T. Andreev, A.A., Afanaseva, N.B., Berezina, N.A. Bezusko, L.G., Blyakharchuk, T.A., Bolikhovskaya, N.S., Cheddadi, R. Chernavskaya, M.M., Chernova, G.M., Dorofeyuk, N.I., Dirksen, V.G., Elina, G.A., Filimonova, L.V., Glebov, F.Z., Guiot, J., Gunova, G.S., Harrison, S.P., Jolly, D. Khomutova, V.I., Kvavadze, E.V., Osipova, I.M., Panova, N.K., Prentice, I.C. Saarse, L., Sevastyanov, D.V., Volkova, V.P., Zernitskaja, V.P., 1998. Present-day and mid-Holocene biomes reconstructed from pollen and plant macrofossi data from former Soviet Union and Mongolia. Journal of Biogeography 25 1029-1053.

Tarasov, P., Dorofeyuk, N., Metel'tseva, E., 2000. Holocene vegetation and climate changes in Hoton-Nur basin, northwest Mongolia. Boreas 29/2, 117-126. 
Tarasov, P., Bezrukova, E., Karabanov, E., Nakagawa, T., Wagner, M., Kulagina, N., Letunova, P., Abzaeva, A., Granoszewski, W., Riedel, F., 2007a. Vegetation and climate dynamics during the Holocene and Eemian interglacials derived from Lake Baikal pollen records. Palaeogeography, Palaeoclimatology, Palaeoecology 252 (3-4), 440-457.

Tarasov, P., Williams, J., Andreev, A., Nakagawa, T., Bezrukova, E., Herzschuh, U. Igarashi, Y., Müller, S., Werner, K., Zheng, Z., 2007b. Satellite- and pollen-based quantitative woody cover reconstructions for northern Asia: Verification and application to late-Quaternary pollen data. Earth and Planetary Science Letters 264, 284-298.

Texier, D., de Noblet, N., Harrison, S.P., Haxeltine, A., Jolly, D., Joussaume, S., Laarif, F., Prentice, I.C., Tarasov, P., 1997. Quantifying the role of biosphere-atmosphere feedbacks in climate change: coupled model simulations for 6000 years BP and comparison with palaeodata for northern Eurasia and northern Africa. Climate Dynamics $13,865-882$.

Trautmann, W., 1953. Zur Unterscheidung fossiler Spaltofnungen der mitteleuropaeischen Coniferen. Flora 140, 523-533.

Turkia, J., Lepisto, L., 1999. Size variations of planktonic Aulacoseira Thwaites (Diatomae) in water and in sediment from Finnish lakes of varying trophic state. Journal of Plankton Research 21 (4), 757-770.

Tyson, R.V., 1995. Sedimentary Organic Matter, Organic Facies and Palynofacies. Chapman and Hall, London.

van Geel, B., 2001. Non-pollen palynomorphs. In: Smol, J.P., Birks, H.J.B., Last, W.M. (Eds.), Terrestrial Algal and Siliceous Indicators. Tracking Environmental Changes Using Lake Sediments, Vol. 3. Kluwer Academic Press, Dordrecht, pp. 99-119. van Geel, B., Buurman, J.J., Brinkkemper, O., Schelvis, J.J., Aptroot, A., van Reenen, G., Hakbijl, T., 2003. Environmental reconstruction of a Roman Period settlement site in Uitgeest (The Netherlands), with special reference to coprophilous fungi. Journal of Archaeological Science 30, 873-883.

Volkova, E.A., 1994. Botanicheskaya geographiya Mongolskogo i Gobiiskogo Altaya. St.-Petersburg (in Russian).

Walter, M., Wünnemann, B., Tschimeksaichan, A., 2003. Seen und Paläoseen in der Mongolei und Nordwestchina. Petermanns Geographische Mitteilungen 147, 40-47.

Westover, K.S., Fritz, S.C., Blyakharchuk, T.A., Wright, H.E., 2006. Diatom paleolimnological record of Holocene climatic and environmental change in the Altai Mountains, Siberia. Journal of Paleolimnology 35, 519-541.

Wei, K., Gasse, F., 1999. Oxygen isotopes in lacustrine carbonates of West China revisited: implications for post glacial changes in summer monsoon circulation. Quaternary Science Reviews 18 (12), 1315-1334.

Winkler, M.G., Wang, P.K., 1993. The late-Quaternary vegetation and climate in China. In: Wright, H.E., Kutzbach, J.E., Webb III, T., Ruddiman, W.D., StreetPerrott, F.A., Bartlein, P.J. (Eds.), Global climates since the last Glacial Maximum. University of Minnesota Press, Minneapolis, pp. 221-261.

Wohlfarth, B., Tarasov, P., Bennike, O., Lacourse, T., Subetto, D., Torssander, P., Romanenko, F., 2006. Late glacial and Holocene palaeoenvironmental changes in the Rostov-Yaroslavl' area, West Central Russia. Journal of Paleolimnology 35 (3), 543-569.

Yuan, D.X., Cheng, H., Edwards, R.L., Dykoski, C.A., Kelly, M.J., Zhang, M.L., Qing, J.M., Lin, Y.S., Wang, Y.J., Wu, J.Y., Dorale, J.A., An, Z.S., Cai, Y.J., 2004. Timing, duration, and transitions of the Last Interglacial Asian monsoon. Science 304, 575-578.
1847 1848 